\title{
Ion channels, phosphorylation and mammalian sperm capacitation
}

\begin{abstract}
Pablo E Visconti ${ }^{1}$, Dario Krapf ${ }^{2}$, José Luis de la Vega-Beltrán ${ }^{3}$, Juan José Acevedo ${ }^{4}$ and Alberto Darszon ${ }^{3}$
Sexually reproducing animals require an orchestrated communication between spermatozoa and the egg to generate a new individual. Capacitation, a maturational complex phenomenon that occurs in the female reproductive tract, renders spermatozoa capable of binding and fusing with the oocyte, and it is a requirement for mammalian fertilization. Capacitation encompasses plasma membrane reorganization, ion permeability regulation, cholesterol loss and changes in the phosphorylation state of many proteins. Novel tools to study sperm ion channels, image intracellular ionic changes and proteins with better spatial and temporal resolution, are unraveling how modifications in sperm ion transport and phosphorylation states lead to capacitation. Recent evidence indicates that two parallel pathways regulate phosphorylation events leading to capacitation, one of them requiring activation of protein kinase $A$ and the second one involving inactivation of ser/thr phosphatases. This review examines the involvement of ion transporters and phosphorylation signaling processes needed for spermatozoa to achieve capacitation. Understanding the molecular mechanisms leading to fertilization is central for societies to deal with rising male infertility rates, to develop safe male gamete-based contraceptives and to preserve biodiversity through better assisted fertilization strategies.
\end{abstract}

Asian Journal of Andrology (2011) 13, 395-405; doi:10.1038/aja.2010.69

Keywords: capacitation; ion channels; lipids; phosphorylation; sperm

\section{INTRODUCTION}

On September 2010, Dr Robert Edwards was awarded the Nobel Prize for the development of human in vitro fertilization (IVF) therapy. Since the first successful 'Test-Tube' baby was born in 25 July 1978, ${ }^{1}$ over four million babies were conceived with this methodology. This outstanding landmark represented by Louise Joy Brown's birth was achieved almost 100 years after the first IVF attempts in mammals. The difficulties to attain mammalian IVF were inherent to a lack of knowledge on how gametes behave in in vitro systems. It was not until the early 1950s that Austin ${ }^{2}$ and Chang ${ }^{3}$ independently demonstrated that sperm had to reside in the female reproductive tract for a period of time before becoming able to fertilize an egg. The physiological changes that occur to the sperm in their transit toward the egg were collectively defined as 'sperm capacitation'. The discovery of capacitation was essential for IVF because this finding made researchers aware that to acquire fertilizing capacity, mammalian sperm need to be in contact with molecules present in the female. Less than 10 years later, this discovery was followed by the first successful mammalian IVF when Chang showed that eggs from a black rabbit fertilized in vitro by capacitated sperm from a black male, and transferred to a white rabbit female, resulted in black offspring. ${ }^{4}$

The relevance of sperm capacitation for IVF increased the need to further study this process at the molecular level. Inherent to the initial studies on capacitation was the understanding that this process comprises multiple signaling events. For example, as soon as sperm are ejaculated, they become actively motile; however, they are still unable to penetrate the egg layers. In part, this motility activation is regulated by changes in the ionic environment surrounding the sperm. Later on, sperm undergo other modifications in their motility pattern known as hyperactivation. Although the exact role of hyperactivation is not clear yet, this process is believed to be related to the release of sperm from the oviduct reservoirs as well as to help sperm to penetrate the extracellular matrix of the egg. ${ }^{5}$ Besides changes in the flagellum, capacitation is also related to the ability of sperm to undergo a physiologically induced acrosome reaction. Interestingly, these processes occurring respectively in the tail and the head are temporally coordinated and are activated by similar signaling pathways. Finally, although the acrosome reaction is needed for fertilization and initially this process was considered part of the capacitation process, current views considered that the acrosome reaction is a post-capacitation event. $^{6}$

In the last years, state-of-the-art techniques are being used to elucidate the molecular basis of sperm capacitation. Among them it is possible to highlight: (i) genetically modified mice models; (ii) global approaches to identify proteins present in different sperm structures; and (iii) whole cell patch clamp techniques to directly measure ion transport in differentiated sperm. Although this review will mention some of the most critical discoveries in the field of capacitation, it will

${ }^{1}$ Department of Veterinary and Animal Science, Paige Labs, University of Massachusets, Amherst MA 01003, USA; ${ }^{2}$ Institute of Molecular and Cell Biology of Rosario (CONICETUNR) and Área Biología, Facultad de Ciencias Biológicas y Farmacéuticas, UNR, Rosario 2000, Argentina; ${ }^{3}$ Departamento de Genética del Desarrollo y Fisiología Molecular, Instituto de Biotecnología, Universidad Nacional Autónoma de México (UNAM), Cuernavaca, Morelos, C.P. 62510, México and ${ }^{4}$ Departamento de Fisiología y Farmacología, Facultad de Medicina, Universidad Autónoma del Estado de Morelos, Cuernavaca, C.P. 62510, México

Correspondence: Dr A Darszon (darszon@ibt.unam.mx)

Received: 21 January 2011; Revised: 11 March 2011; Accepted: 14 March 2011 
be mostly focused on the analysis of two aspects of capacitation: (i) the regulation of the capacitation-associated changes in ion transport including those that are involved in the modulation of the sperm plasma membrane potential (Em); and (ii) the regulation of the capacitation-associated changes in phosphorylation. For more information, some other excellent reviews on capacitation have been published in recent years. $^{7-12}$

\section{REGULATION OF ION FLUXES DURING SPERM CAPACITATION}

Cells expend a significant portion of their energetic resources building and maintaining ion concentration gradients across the membrane through the use of pumps and ion transporters. They use these stored resources to decode information from their surroundings and their interior. Ion channels and certain transporters capitalize these resources as their activation can change the electrical potential of the cell and the concentrations of second messengers within a wide time range, depending on the modes of channel regulation. In particular, ion channels can be opened to allow the flow of millions of ions per second across the membrane down their electrochemical gradient by small conformational changes induced by voltage, ligands, phosphorylation changes, membrane pressure and other signaling events. ${ }^{13}$

As part of their transit through the epididymis, sperm are exposed to conditions very different to the ones that they will encounter in the seminal fluid and in the female tract. In comparison with other body fluids, the epididymis lumen contains lower levels of $\mathrm{Na}^{+}$, higher levels of $\mathrm{K}^{+}$and lower levels of $\mathrm{Cl}^{-}$. Osmolarity is compensated by organic anions such as carnitin, phosphocoline and glycerylphosphorylcholine. ${ }^{14}$ Most interestingly, the epididymal fluid is maintained at a low $\mathrm{pH}$ by a finely regulated epithelial release of $\mathrm{H}^{+}$and uptake of $\mathrm{HCO}_{3}^{-}$. This reduced $\mathrm{pH}$ is essential to maintain functionally competent sperm. ${ }^{15}$

After ejaculation, when spermatozoa are transferred to and navigate through the female tract, extracellular ion concentrations and osmolarity change again. In this case, extracellular $\left[\mathrm{K}^{+}\right]\left(\left[\mathrm{K}^{+}\right]_{\mathrm{e}}\right)$ is reduced and $\left[\mathrm{HCO}_{3}^{-}\right]_{\mathrm{e}}$ and $\left[\mathrm{Na}^{+}\right]_{\mathrm{e}}$ are increased in relation to seminal fluid ion concentrations. $\mathrm{HCO}_{3}^{-}$increases from $\sim 4 \mathrm{mmol} \mathrm{l}^{-1}$ in the epididymis ${ }^{16,17}$ to $>20 \mathrm{mmol}^{-1}$ in the oviduct ${ }^{18}$ immediately activating mouse sperm flagellar beating. In this new milieu, sperm undergo capacitation, another extra testicular maturational change. As mentioned in the introductory paragraphs, discovery of capacitation made possible mammalian IVF. Initial experiments on this front focused in development of incubation media that support capacitation in vitro. Although each species has specific requirements, there is a consensus that certain components of the capacitation media are universal and close to the composition of the oviductal fluid. Among them, all capacitation media contained close-to-serum levels of $\mathrm{Na}^{+}, \mathrm{K}^{+}$, $\mathrm{Cl}^{-}, \mathrm{Ca}^{2+}$ and $\mathrm{HCO}_{3}^{-} \cdot{ }^{19,20}$ In addition, these media contain energy metabolites (such as glucose, pyruvate and lactate) and a protein source that usually is serum albumin. Although the precise role of these molecules in capacitation is still under study, work from several groups is starting to elucidate some of their actions. A schematic representation of the roles and interrelationships between the ion transporters suspected to participate in capacitation is illustrated in Figure 1.

\section{Intracellular $\mathrm{Ca}^{2+}$ and $\mathrm{pH}$ changes}

$\mathrm{Ca}^{2+}$ and $\mathrm{H}^{+}$play a preponderant role during capacitation, ${ }^{20}$ and both $\left[\mathrm{Ca}^{2+}\right]_{i}$ and $\mathrm{pH}_{\mathrm{i}}$ increase during this process. ${ }^{21-26}$ Though usually capacitating media contain $\sim 2 \mathrm{mmoll}^{-1} \mathrm{Ca}^{2+}, 100-200 \mu \mathrm{moll}^{-1}$ is enough to capacitate mouse sperm. ${ }^{27,28}$ Recent work exploring the $\left[\mathrm{Ca}^{2+}\right]_{\mathrm{e}}$ requirement for the $\mathrm{HCO}_{3}^{-}$stimulation of sperm motility revealed that additionally to its critical role as second messenger, $\mathrm{Ca}^{2+}$ can act as a first messenger. $\mathrm{A} \mathrm{Ca}^{2+}$ sensing receptor has been cloned ${ }^{29}$ and proposed to participate in the $\mathrm{HCO}_{3}^{-}$-induced acceleration of mouse sperm flagellar beat frequency. ${ }^{30}$ However, how the $\left[\mathrm{Ca}^{2+}\right]_{i}$ increase required for capacitation occurs is not fully answered (Figure 1). Some transporters appear as main candidates responsible for $\mathrm{Ca}^{2+}$ influx: $\mathrm{Ca}_{\mathrm{V}}$ and CatSper channels, $\mathrm{Na}^{+} / \mathrm{Ca}^{2+}$ exchangers, $\mathrm{Ca}^{2+}$ ATPases and the novel STIM and ORAI. On the other hand, $\mathrm{Ca}^{2+}$ released from intracellular stores must also be considered. In this regard, the main candidates would be: IP3 receptors, ryanodine receptors, TPC proteins, SERCA and SPM ATPases. We will briefly describe the characteristics and possible relation of CatSpers and $\mathrm{Ca}_{\mathrm{V}}$ s to sperm capacitation.

\section{$\mathrm{Ca}^{2+}$ channels}

CatSpers. Bioinformatics and gene-targeting strategies have revealed that mouse spermatozoa possess sperm-specific subunits of a new family of cation channels named CatSper channels (cation channel of spermatozoa). In addition to mammals, these channels are also present in reptiles, tunicates, echinoderms and cnidarians. ${ }^{31,32}$ This novel class of $\mathrm{Ca}^{2+}$ channels has been shown to be essential for mammalian hyperactivated sperm motility, sperm detachment from the female reproductive tract ${ }^{33}$ and egg coat penetration and fertility. ${ }^{32,34,35}$ CatSper mutations in humans have been associated to infertility. ${ }^{36}$ At present, the family has four members (CatSpers1-4), all most likely found in the principal piece of the flagella, plus two additional auxiliary subunits, CatSperB and G. These later subunits are transmembrane proteins, have large extracellular domains and have unknown functions. ${ }^{34,37,38}$ Interestingly, it has been noted that as in other voltage-dependent ion channels, extracellular ligand binding to auxiliary subunits could modulate CatSper's activity. ${ }^{39}$

All four CatSper subunits (1-4) are needed for functional expression in mouse sperm, as knockout of any one of them results in absence of the other subunits in mature sperm with the consequent observation of male infertility and the lack of the CatSper associated currents recorded by sealing on cytoplasmic droplet of epididymal sperm. ${ }^{34,35,40}$ CatSper1 null male mice also display defects in cAMP and depolarization-induced $\mathrm{Ca}^{2+}$ entry. ${ }^{34,41}$ The pore-forming subunits of CatSper channels are like those of voltage-dependent $\mathrm{K}^{+}$channels displaying six transmembrane spanning domains with a P-loop between transmembrane domains S5 and S6. It is thought that the channel would be formed by four of these subunits. However, their selectivity filter sequences are closer to those of $\mathrm{Ca}_{\mathrm{V}}$ channels constituted by a single polypeptide with 24 transmembrane domains. CatSper channels are constitutively active, weakly voltage-dependent, $\mathrm{Ca}^{2+}$ selective and strongly potentiated by intracellular alkalinization. ${ }^{34,42}$ Unfortunately, it has been impossible to heterologously express CatSper channels; thus their characterization has been restricted to optical, electrophysiological and biochemical experimental strategies in mouse and human sperm.

The high $\mathrm{pH}_{\mathrm{i}}$ sensitivity of CatSper is likely due to its CatSper1 subunit which contains an intracellular C-terminal domain rich in histidines. Although not yet demonstrated, capacitation-associated $\mathrm{pH}_{\mathrm{i}}$ changes may activate this channel with the consequent increase in $\left[\mathrm{Ca}^{2+}\right]_{i}$. Related to the $\mathrm{pH}_{\mathrm{i}}$ regulation might be the well-described cyclic nucleotide-induced $\left[\mathrm{Ca}^{2+}\right]_{i}$ increase, ${ }^{43}$ as neither cAMP nor cGMP elevate $\left[\mathrm{Ca}^{2+}\right]_{i}$ in sperm from CatSper null mice. It is worth noting that none of the CatSper subunits have a cyclic nucleotide-binding sequence. 

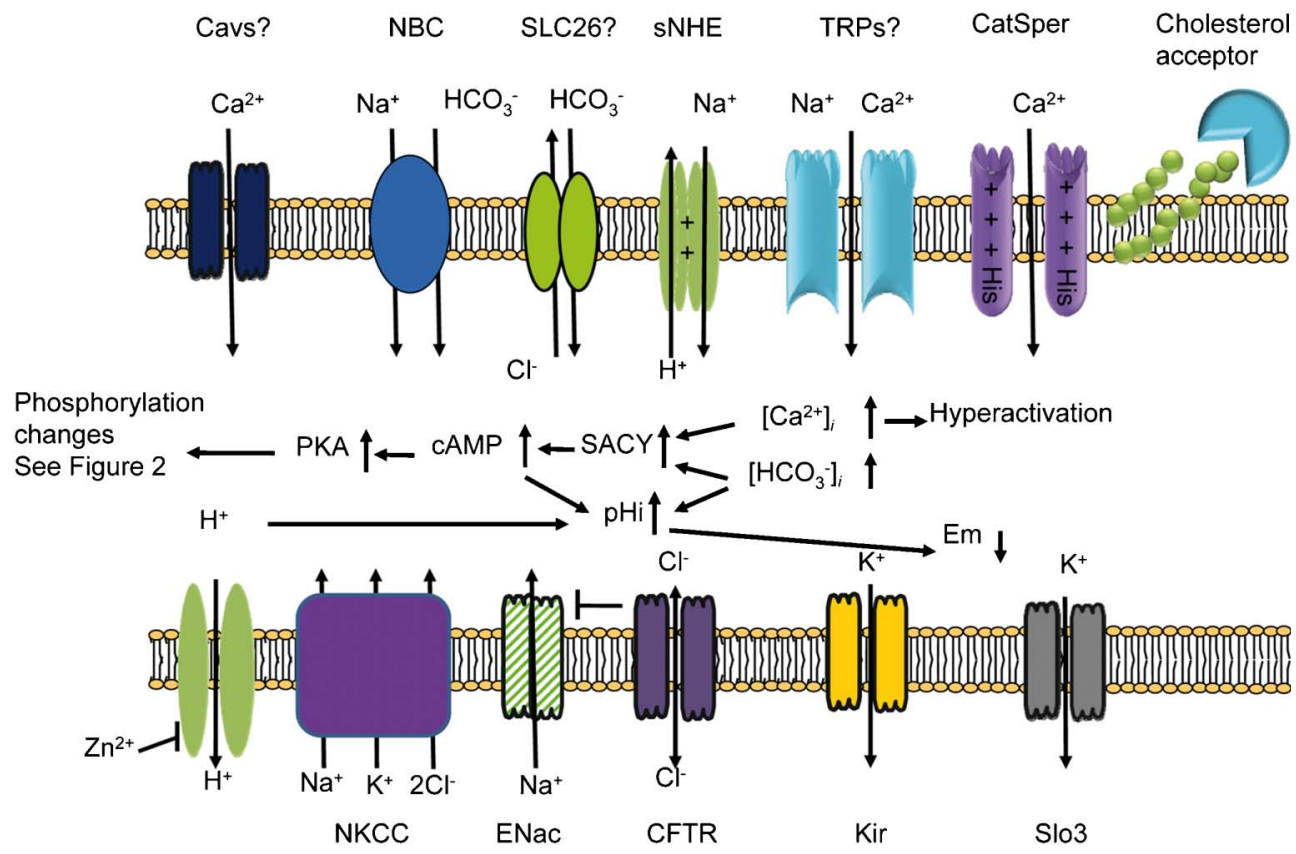

Figure 1 Ion permeability model. This figure illustrates a schematic representation of the roles and interrelationships between the ion transporters suspected to participate in capacitation. Capacitation and hyperactivation take place during sperm transit through the female tract and have parallel but also intercrossing pathways. Cholesterol removal from the sperm plasma membrane by albumin in the female tract modifies several membrane properties. Albumin can also directly stimulate CatSper channels, increasing $\left[\mathrm{Ca}^{2+}\right]_{i}$. The $\mathrm{HCO}_{3}{ }^{-}$increase experienced by sperm upon entering the female reproductive tract elevates intracellular $\mathrm{HCO}_{3}{ }^{-}$possibly through a NBC which would cause a hyperpolarization and stimulation of SACY, producing cAMP. In addition to triggering the phosphorylation cascades (see Figure 2), CAMP may activate the $\mathrm{SNHE}$ which together with the proton channel $\left(\mathrm{H}_{\mathrm{V}}\right)$, possibly stimulated by $\mathrm{Zn}^{2+}$ removal in the female reproductive tract, ${ }^{35}$ would raise $\mathrm{pH} \mathrm{H}_{\mathrm{i}}$ and activate CatSper and Slo3 channels. CAMP would also activate CFTR and participate in closing ENaCs which together with $\mathrm{K}^{+}$channels hyperpolarize sperm. The $\left[\mathrm{Ca}^{2+}\right]_{i}$ increase may influence glycolysis and the axoneme activity promoting hyperactivated motility. Several $\mathrm{Ca}^{2+}$ mobilizing pumps (PMCA4 and SPCA1) and channels (IP3R, RyR and TRPs) may also participate during $\mathrm{Ca}^{2+}$ signaling. Not all sperm species undergo an Em hyperpolarization associated to capacitation like mouse; the channels and transporters that may contribute to this hyperpolarization are indicated. CFTR, cystic fibrosis transmembrane regulator; Em, membrane potential; IP3R, IP3 receptor; NBC, $\mathrm{Na}^{+} / \mathrm{HCO}_{3}{ }^{-}$cotransporter; NKCC, $\mathrm{Na}^{+} / \mathrm{K}^{+} / \mathrm{Cl}^{-}$cotransporter; PKA, protein kinase A; RyR, ryanodine receptor; SACY, soluble adenylyl cyclase; sNHE, sperm $\mathrm{Na}^{+} / \mathrm{H}^{+}$exchanger; TRP, transient receptor potential.

Alternatively, cyclic nucleotides may regulate CatSper increasing $\mathrm{pH}_{\mathrm{i}}$ by activating a sperm specific $\mathrm{Na}^{+} / \mathrm{H}^{+}$exchanger (sNHE) (see below). ${ }^{32,34}$ Finally, recent work from the Ren's laboratory suggests that CatSper may contribute to the $\left[\mathrm{Ca}^{2+}\right]_{i}$ increase that accompanies the acrosome reaction. ${ }^{44}$ However, though sperm from CatSper null mice lack a zona pellucida (ZP)-induced $\mathrm{Ca}^{2+}$ uptake component, they undergo tyrosine phosphorylation, ${ }^{41}$ a $\mathrm{ZP}$-induced acrosome reaction and they can fertilize zona-free eggs. ${ }^{34,35}$ Interestingly, within the time resolution of $\mathrm{Ca}^{2+}$ measurements in this work, the $\mathrm{ZP}$-induced $\mathrm{Ca}^{2+}$ increase starts in the flagellum where CatSpers are present. How ZP proteins regulate CatSper in the flagellum is not yet known.

$C a_{V}$ s. These $\mathrm{Ca}^{2+}$ channels convert Em changes into $\mathrm{Ca}^{2+}$ signals. The subunit of these channels contains the ion permeation pathway which is encoded by a family of at least 10 genes. $\mathrm{Ca}_{\mathrm{V}}$ channels have been cataloged in two major functional classes: high voltage-activated and low voltage-activated. Though transcripts and proteins for both types of $\mathrm{Ca}_{\mathrm{V}}$ have been detected in mammalian sperm, ${ }^{45}$ electrophysiological evidence has mainly revealed the functional presence of $\mathrm{Ca}_{\mathrm{V}} 3$ channels in mouse and human spermatogenic cells ${ }^{46-48}$ and in mouse testicular sperm. ${ }^{49}$ Weak depolarizations can open $\mathrm{Ca}_{\mathrm{V}} 3$ channels which are encoded by the $\mathrm{Ca}_{\mathrm{V}} 3$ subfamily of genes $\left(\mathrm{Ca}_{V} 3.1\right.$ to $\left.C a_{V} 3.3\right) .{ }^{49,50}$ However, $\mathrm{Ca}_{\mathrm{V}} 3$ channels begin inactivating at relatively hyperpolarized potentials (about $-60 \mathrm{mV}$ ); at the Em of noncapacitated sperm (about $-40 \mathrm{mV}$ ) they are inactivated. ${ }^{47,51,52}$ As the pharmacology of the mouse sperm acrosome reaction and at least part of the $\mathrm{Ca}^{2+}$ influx associated to it, are consistent with that of $\mathrm{Ca}_{\mathrm{V}} 3$ channels, it was proposed, though now debated, ${ }^{34}$ that they participate in this important reaction. ${ }^{53}$ It turns out that $C a_{V} 3.1$ and $C a_{V} 3.2$ null mice are fertile ${ }^{54,55}$ and though $\mathrm{Ca}_{\mathrm{V}} 3$ currents have been recorded in mouse testicular sperm, ${ }^{49}$ no $\mathrm{Ca}_{\mathrm{V}}$ currents have been detected in epididymal sperm. ${ }^{34}$ These findings certainly question the role of $\mathrm{Ca}_{\mathrm{V}} 3$ and in general $\mathrm{Ca}_{\mathrm{V}}$ channels in sperm physiology. Resolving this matter requires further studies since $\left[\mathrm{Ca}^{2+}\right]_{i}$ measurements and their pharmacology are consistent with the presence and participation of certain $\mathrm{Ca}_{\mathrm{V}}$ channels in sperm physiology. ${ }^{56-58}$

If $\mathrm{Ca}_{\mathrm{V}}$ channels were involved in the acrosome reaction, sperm Em should hyperpolarize during capacitation to remove their inactivation before they could open and trigger this process. ${ }^{59}$ Indeed, single-cell Em measurements indicated that the Em of $~ 50 \%$ of mouse sperm remain close to that of uncapacitated sperm, while the rest hyperpolarize to $-80 \mathrm{mV}$, a potential that can remove inactivation from low voltage-activated $\mathrm{Ca}^{2+}$ channels. ${ }^{51}$ These experiments suggest that only the hyperpolarized population can undergo the AR when exposed to solubilized ZP (see the section on 'Em changes').

\section{Intracellular $\mathrm{pH}$ regulation}

As discussed earlier, mammalian sperm capacitation requires $\mathrm{HCO}_{3}^{-}$. Uptake of this anion contributes to the $\mathrm{pH}_{\mathrm{i}}$ increase that accompanies this process. ${ }^{21,22,60}$ In addition, $\mathrm{HCO}_{3}^{-}$influx hyperpolarizes mouse sperm depending on the concentration of external $\mathrm{Na}^{+}$, suggesting the 
involvement of an electrogenic $\mathrm{Na}^{+} / \mathrm{HCO}_{3}^{-}$cotransporter during capacitation. ${ }^{60}$

Regulation of sperm $\mathrm{pH}_{\mathrm{i}}$ is not only fundamental for capacitation, but also for motility and the acrosome reaction. As mentioned, sperm express a specific member of the mammalian NHE superfamily of $\mathrm{Na}^{+} / \mathrm{H}^{+}$exchangers, sNHE. ${ }^{61-63}$ It is localized on the principal piece of the sperm flagellum and predicted to have 14 membrane-spanning helices. sNHE contains a nucleotide-binding domain close to its intracellular C-terminus and four putative transmembrane helices analogous to the voltage sensor of voltage-dependent channels. ${ }^{64}$ These distinctive characteristics suggest that SNHE may be regulated by cyclic nucleotides and Em, ${ }^{65}$ in addition to phosphorylation and protein interactions. ${ }^{61}$ Sperm from sNHE null male mice are immotile and infertile, and can be rescued adding permeable analogs of cAMP or $\mathrm{NH}_{4} \mathrm{Cl}$. sNHE and the soluble adenylyl cyclase (SACY) may form a transduction complex to efficiently regulate $\mathrm{pH}_{\mathrm{i}}, \mathrm{HCO}_{3}^{-}$, cAMP and sperm motility, as the exchanger is required for the full length expression of SACY. ${ }^{63,65}$

Recent evidence has revealed that mammalian sperm, particularly those of human, express $\mathrm{H}_{\mathrm{V}}$ channels in the flagella. ${ }^{35}$ These channels may participate in the $\mathrm{pH}_{\mathrm{i}}$ increase necessary for capacitation. Since protein kinase $\mathrm{C}$ (PKC) regulates this type of channel in other cell types, an interesting possibility would be that this regulation is conserved in sperm. ${ }^{66}$ In mouse sperm, it has been shown that $\mathrm{H}_{\mathrm{V}}$ channels do not play a preponderant role in $\mathrm{pH}_{\mathrm{i}}$ regulation; ${ }^{35}$ therefore, it is likely that $\mathrm{pH}_{\mathrm{i}}$ relies on the regulation of sNHE as suggested by the sterile phenotype of sNHE null mice. ${ }^{63}$ In this respect, analysis of its sequence predicts that the sNHE is voltage-dependent suggesting that the hyperpolarization that occurs during mouse sperm capacitation could stimulate this exchanger.

\section{Em changes}

In sperm, as in most cells, the internal ion concentrations are markedly different from those in the extracellular medium. These differences result from the relative ion permeability of the plasma membrane to each of the ions found in the inner and outer media given by the specific ion channels and transporters present in the cell, to the gradients they establish and the metabolic state of the cell. At rest, the balance of these fluxes, gradients and permeabilities results in an electric potential, known as the resting Em. Before capacitation mouse sperm are relatively depolarized (Em: about from -35 to $-45 \mathrm{mV}$ ) and become hyperpolarized (about $-70 \mathrm{mV}$ ) during capacitation. ${ }^{51,60,67,68}$ This change results from a combination of electrogenic ion permeability alterations that shift the Em towards the $\mathrm{K}^{+}$equilibrium potential (about $\left.-90 \mathrm{mV}\right){ }^{60,69}$ Several types of $\mathrm{K}^{+}$channels have been detected in testis, spermatogenic cells and sperm using molecular, electrophysiological and biochemical tools (see the section on ' $\mathrm{K}^{+}$channels'). ${ }^{67,70-73}$ It has been mentioned that capacitation-associated hyperpolarization may increase $\mathrm{pH}_{\mathrm{i}}$-stimulating $\mathrm{sNH}$ and consequently CatSper. ${ }^{32}$ However, a $\mathrm{pH}_{\mathrm{i}}$ increase shifts the CatSper current-voltage curve toward more negative membrane potential values. ${ }^{42}$ Considering that CatSper is activated by membrane depolarization, hyperpolarization may have a dual effect on this channel regulated by a subtle balance between these variables, further influenced by cAMP levels. Because capacitation prepares the sperm to undergo the AR, it has been proposed that the capacitation-associated hyperpolarization could also regulate the ability of sperm to generate transient $\left[\mathrm{Ca}^{2+}\right]_{i}$ elevations during the AR induced by physiological agonists (e.g., ZP). ${ }^{46,47,51}$
In the absence of bovine serum albumin and $\mathrm{HCO}_{3}^{-}$, mouse sperm at $\mathrm{pH} 7.2$ do not hyperpolarize which suggests that cholesterol removal and $\mathrm{HCO}_{3}^{-}$somehow regulate the sperm Em changes that occur during capacitation. As in vitro capacitation also depends on the presence of $\mathrm{Na}^{+}$and $\mathrm{Cl}^{-}$in the medium, ${ }^{74,75}$ other ion channels and transporters are likely to regulate sperm Em and intervene in this maturational process. Furthermore, $50 \mathrm{mmoll}^{-1}$ external $\mathrm{KCl}$ inhibits hyperpolarization and capacitation in mouse sperm. ${ }^{51}$

\section{$\mathrm{Na}^{+}$influences the sperm Em}

ENaCs. Addition of $\mathrm{Na}^{+}$to the external media depolarizes mouse sperm more before than after capacitated. This depolarization is very sensitive to amiloride. Indeed, ENaCs, amiloride-sensitive $\mathrm{Na}^{+}$channels that are expressed in many invertebrate and vertebrate cell types, are present in mouse and human sperm. ${ }^{76}$ These channels may be regulated by $\mathrm{pH}, \mathrm{Ca}^{2+}, \mathrm{Na}^{+}, \mathrm{Cl}^{-}$and phosphorylation, ${ }^{77}$ parameters that change during capacitation. The $\mathrm{ENaC} \alpha$ - and $\delta$-subunits were detected in the sperm flagellar mid-piece and acrosome region, respectively. ${ }^{76}$ These channels are $\mathrm{Na}^{+}$-selective, amiloride-sensitive and contribute to the resting Em in cells by displacing it towards the $\mathrm{Na}^{+}$equilibrium potential. ${ }^{78}$ Both mouse spermatogenic cells ${ }^{76}$ and testicular sperm display amiloride-sensitive inward $\mathrm{Na}^{+}$currents whose characteristics match those of ENaCs. Notably, permeable cAMP analogs which induce in vitro capacitation decrease the sperm depolarization induced by addition of external $\mathrm{Na}^{+}$. These experiments are consistent with the hypothesis that elevation of cAMP levels during sperm capacitation decreases $\mathrm{ENaC}$ activity and contribute to the hyperpolarization needed for this process to occur.

\section{$\mathrm{K}^{+}$channels}

As mentioned earlier, mouse sperm hyperpolarize from about -40 to about $-70 \mathrm{mV}$ during capacitation. ${ }^{51,67}$ The involvement of $\mathrm{K}^{+}$channels in this change was proposed since it was affected by external $\mathrm{K}^{+}$ and $\mathrm{K}^{+}$-channel blockers. ${ }^{34,51,67,70}$ Spermatogenic cells and sperm have been reported to possess $\mathrm{Ca}^{2+}$-activated $\mathrm{K}^{+}$channels, ${ }^{71}$ voltage-gated $\mathrm{K}^{+}$channels, ${ }^{72,73}$ two-pore domain $\mathrm{K}^{+}$channels, ${ }^{79}$ inwardly rectifying $\mathrm{K}^{+}$(Kir) channels ${ }^{34,67,70}$ and Slo3 $\mathrm{K}^{+}$channels. ${ }^{49,80-84}$ Below we will discuss the $\mathrm{K}^{+}$channels that have been proposed to participate in capacitation.

Kirs. Kir channels move $\mathrm{K}^{+}$easier into the cell than out. The Kir family is constituted by seven subfamilies (Kir1-7). These subfamilies can be further divided into four functional groups: constitutively active classical Kir channels (Kir2), G protein-gated Kir channels (Kir3), ATP-sensitive $\mathrm{K}^{+}$channels (Kir6) linked to cellular metabolism and $\mathrm{K}^{+}$transport channels (Kir1, 4, 5 and 7). Among many cell functions, Kir channels are important in maintaining Em and $\mathrm{K}^{+}$ homeostasis, membrane excitability, vascular tone, heart rate and insulin secretion. Intracellular substances such as $\mathrm{Mg}^{2+}$ and polyamines block the pore causing inward rectification. Ions, phospholipids and proteins modulate Kir channel activity. A Kir subunit is basically made up of two transmembrane helices with cytoplasmic $\mathrm{NH}_{2}$ and $\mathrm{COOH}$ termini and an extracellular loop which folds back to form the pore-lining ion selectivity filter. Four of these homo- or heteromeric subunits constitute a functional Kir channel. ${ }^{80}$

Patch-clamp recordings in mouse spermatogenic cells revealed Kir currents sensitive to $\mathrm{Ba}^{2+}$, glucose, tolbutamide and glibenclamide. ${ }^{34,67,70}$ More recently these compounds were shown to block $\mathrm{K}^{+}$currents in mouse testicular sperm; ${ }^{81}$ they also inhibited the hyperpolarization associated to mouse sperm capacitation and, at least partially the $A R .{ }^{34,67,70}$ 
Tolbutamide and glibenclamide are sulfonylureas known to block Kir channels regulated by ATP ( $\mathrm{K}_{\mathrm{ATP}}$ channels). $\mathrm{K}_{\mathrm{ATP}}$ channels are formed from Kir6 subunits and ATP-binding cassette sulfonylurea receptor (SUR) proteins. ${ }^{85}$ Transcripts for the $\mathrm{K}_{\mathrm{ATP}}$ channel subunits SUR1, SUR2, Kir6.1 and Kir6.2 were detected in elongated spermatids and the expressed proteins immunolocalized in mature mouse sperm. ${ }^{70}$

Kir channels are in general inhibited by low $\mathrm{pH}_{\mathrm{i}}{ }^{80}$ As sperm $\mathrm{pH}_{\mathrm{i}}$ is relatively acidic before capacitation, it could maintain Em depolarized keeping $\mathrm{Ca}_{\mathrm{V}}$ channels inactivated and unable to cause unregulated $\mathrm{Ca}^{2+}$ entry and the acrosome reaction. ${ }^{22}$ In spite of the structural similarities between different Kirs, cholesterol affects them differentially. Its depletion increases Kir2 current density, while it inhibits Kir4 channels. ${ }^{86}$ Sperm capacitation is accompanied by activation of the cAMP/protein kinase A (PKA) signaling pathway, cholesterol depletion and a $\mathrm{pH}_{\mathrm{i}}$ increase. ${ }^{87}$ It is therefore feasible that Kir channels such as the $\mathrm{K}_{\mathrm{ATP}}$ channels contribute to the capacitation-associated hyperpolarization in mouse sperm.

Slo3. The Slo gene family of $\mathrm{K}^{+}$channels are formed by an $\alpha$ subunit with a large cytosolic $\mathrm{C}$-terminal containing potential ligand regulation sites and a $\beta$-auxiliary subunit. There are four $\alpha$ subunits, where each type can apparently form a functional tetramer, ${ }^{88}$ and four different $\beta$-subunits that regulate the function and expression of Slo channels. ${ }^{89}$ Specific cytosolic ions regulate each of the subunits: $\mathrm{Ca}^{2+}$ for Slo1, $\mathrm{Na}^{+}$for both Slo2.1 (Slick) and Slo2.2 (Slack), and $\mathrm{H}^{+}$for Slo3. ${ }^{90}$

The Slo3 subunit, cloned many years ago and expressed only in spermatogenic cells and sperm, ${ }^{80,82}$ has only recently been shown to be fundamental for sperm function; ${ }^{49,83} \mathrm{Slo} 3$ null male mice are infertile. ${ }^{84}$ Slo 3 currents in mouse testicular sperm are similarly activated by intracellular alkalinization, depolarization and cAMP, blocked by $1 \mathrm{mmol} \mathrm{l}^{-1} \mathrm{Ba}^{2+}$ and high [TEA] $\left(60 \mathrm{mmol} \mathrm{l}^{-1}\right)$, and poorly $\mathrm{K}^{+}$ selective $\left(\mathrm{PK}^{+} / \mathrm{PNa}^{+}: \sim 8\right)$, as they are when heterologously expressed in oocytes. ${ }^{49}$ These currents are absent in testicular sperm from Slo3 null mice, confirming their identity. ${ }^{84}$

As discussed earlier, under capacitating conditions wild-type mouse sperm hyperactivate, their $\mathrm{pH}_{\mathrm{i}}$ increase and their Em hyperpolarize. In contrast, sperm from Slo3 null mice are unable to swim progressively, to hyperpolarize and to undergo the acrosome reaction. Remarkably, these sperm cannot acrosome react even when exposed to $\mathrm{Ca}^{2+}$ ionophore. These results show that Slo3 channel activation is pivotal for the capacitation-associated processes necessary for fertilization. These considerations also point to this channel as an attractive target for male contraception. ${ }^{84}$

Recent findings revealed that Slo3 channels heterologously expressed are stimulated by PIP2. This also occurs to the corresponding currents in epididymal mouse sperm. These Slo3 currents are inhibited by EGF acting through the EGF receptor, in a PIP2dependent manner. ${ }^{91}$ Further studies are needed regarding the selectivity, voltage dependence and $\beta$-subunit regulation of Slo3 channels in mammalian sperm to fully understand their participation in capacitation and fertilization.

$\mathrm{HCO}_{3}^{-}, \mathrm{Cl}-$ and cystic fibrosis transmembrane regulator (CFTR) $\mathrm{HCO}_{3}^{-}$influences mouse sperm Em in addition to its role regulating SACY. Upon addition of $\mathrm{HCO}_{3}^{-}$, the electrogenic influx of this anion causes a temporal hyperpolarization of mouse sperm that is distinct from the slowly developing hyperpolarization associated to capacitation. In these experiments, $\mathrm{Na}^{+}$replacement from the external media by the non-permeant cation choline ${ }^{+}$does not allow the hyperpolarization induced by adding $\mathrm{HCO}_{3}^{-}$, and inhibits the capacitation-associated increase in protein tyrosine phosphorylation and the preparation for the $\mathrm{ZP}$-induced acrosome reaction. Addition of permeable analogs of cAMP to the choline incubation medium restores protein tyrosine phosphorylation. These findings suggest that a $\mathrm{Na}^{+} / \mathrm{HCO}_{3}^{-}$cotransporter is present in mouse sperm and is coupled to events regulating capacitation. ${ }^{60}$

ENaCs and the CFTR have been found to regulate each other and colocalize in several cell types. ${ }^{92}$ Cystic fibrosis, the most widespread human genetic disease, is caused by mutations in CFTR, a cAMPmodulated, ATP-dependent $\mathrm{Cl}^{-}$channel. ${ }^{93} \mathrm{ENaCs}$ and CFTRs have been detected in the mid-piece of mouse and human sperm flagella. ${ }^{69,94} \mathrm{Em}$ measurements have indicated that cAMP may close ENaCs by activating CFTR and thus contribute to the capacitation associated hyperpolarization. ${ }^{69}$

$\mathrm{Cl}^{-}$transport across the plasma membrane is important for the regulation of cell Em, volume, $\mathrm{pH}_{\mathrm{i}}$ and for $\mathrm{HCO}_{3}^{-}$fluxes. Different $\mathrm{Cl}^{-}$channels, exchangers and cotransporters move this anion. ${ }^{13}$ Sperm capacitation and fertilization require external $\mathrm{Cl}^{-} .{ }^{95,96}$ Evidence indicates that $\left[\mathrm{Cl}^{-}\right]_{\mathrm{i}}$ increases during capacitation; ${ }^{69}$ its influx may be necessary to allow a raise in intracellular $\mathrm{HCO}_{3}^{-}$that would stimulate SACY through $\mathrm{Cl}^{-} / \mathrm{HCO}_{3}^{-}$antiporters. ${ }^{69,96}$ As sperm Em is close to the $\mathrm{Cl}^{-}$equilibrium potential, opening $\mathrm{Cl}^{-}$channels would not allow accumulation of this anion. These considerations point out that it is likely that other $\mathrm{Cl}^{-}$transport systems are present in sperm. From a battery of $\mathrm{Cl}^{-}$ transport antagonists tested in capacitation assays, only general $\mathrm{Cl}^{-}$transport blockers that do not allow identification of specific transporters, such as stilbenes (i.e., DIDS), inhibited tyrosine phosphorylation, hyperactivation and fertilization. These findings are consistent with the presence and importance of $\mathrm{Cl}^{-}$transporters in sperm physiology. Furthermore, as observed in external media without $\mathrm{Cl}^{-}$, bumetanide and furosemide, two $\mathrm{Na}^{+} / \mathrm{K}^{+} /$ $\mathrm{Cl}^{-}$cotransporter (NKCC) inhibitors, reduced sperm tyrosine phosphorylation and hyperactivation. It is worth noting that higher concentrations were needed for this inhibition than those required to antagonize NKCCs. ${ }^{97}$ In addition, external $\mathrm{K}^{+}$, an ion needed for NKCC function, was not required for the increase in tyrosine phosphorylation associated to capacitation. This and the high bumetanide concentrations needed to inhibit may indicate that this antagonist could affect other targets in addition to NKCC. ${ }^{96}$

On the other hand, the $\mathrm{ZP}$-induced acrosome reaction which depends on external $\mathrm{Cl}^{-}, \mathrm{K}^{+}$and $\mathrm{Na}^{+}$, is inhibited at a much lower concentration of bumetanide and furosemide, suggesting that NKCC might participate in the capacitation-dependent preparation of sperm for the acrosome reaction or directly in this reaction. The messenger for this cotransporter and its protein were detected in mouse spermatogenic cells and sperm, respectively. ${ }^{96}$ Interestingly, other conditions that do not inhibit either hyperactivation or the increase in tyrosine phosphorylation, such as CFTR antagonists DPC and inh-172, can block the ZP-induced acrosome reaction. These results suggest that capacitation requires nonlinear signaling paths. In accordance with this hypothesis, although sperm from SACY null mice fail to hyperactivate and to increase their tyrosine phosphorylation, they are able to undergo the ZP-induced acrosome reaction. ${ }^{98}$ Noteworthy, the gen$\mathrm{eral} \mathrm{Cl}^{-}$channel inhibitor niflumic acid inhibited the mouse acrosome reaction initiated by different stimuli, including $\mathrm{ZP}$ and glycine. ${ }^{99}$ In addition, the presence of glycine receptor/ $\mathrm{Cl}^{-}$channel has been shown to be involved in the human zona-induced acrosome reaction. ${ }^{100}$ The 
inhibitor strychnine was also able to inhibit the $\mathrm{Ca}^{2+}$ influx associated with addition of recombinant human $\mathrm{ZP} 3,{ }^{101}$ further substantiating the key role of $\mathrm{Cl}^{-}$influx in the acrosome reaction.

Is sperm hyperpolarization needed for capacitation and if so why? Originally it was argued that mouse sperm needed to hyperpolarize during capacitation to remove inactivation from $\mathrm{Ca}_{V}$ channels so they could open when stimulated by ZP to trigger the acrosome reaction. ${ }^{46,47,51}$ However, the functional involvement of $\mathrm{Ca}_{\mathrm{V}}$ channels in sperm is being questioned. It is worth considering that this hyperpolarization could be required to activate sNHE and increase $\mathrm{pH}_{\mathrm{i}}$, which would in turn stimulate Slo3 and CatSper channels, ${ }^{32}$ and possibly SACY. ${ }^{65}$ In addition, a hyperpolarization would increase the driving force for $\mathrm{Ca}^{2+}$ uptake through other $\mathrm{Ca}^{2+}$ permeable channels such as transient receptor potentials, some of which are activated by alkalinization.

\section{PHOSPHORYLATION EVENTS LINKED TO SPERM CAPACITATION}

\section{cAMP, $\mathrm{HCO}_{3}^{-}$and $\mathrm{Ca}^{2+}$ in SACY regulation}

As mentioned, one critical change in the sperm surrounding milieu after ejaculation is the change in $\mathrm{HCO}_{3}^{-}$concentration. In addition to the aforementioned relevance of this anion to regulate $\mathrm{pH}_{\mathrm{i}}$ and Em, there is a connection between $\mathrm{HCO}_{3}^{-}$and the cAMP pathway. ${ }^{102}$ This landmark observation indicated that $\mathrm{Ca}^{2+}$ upregulated cAMP levels only when $\mathrm{HCO}_{3}^{-}$was present in the incubation medium. This initial finding was followed by experiments in boar sperm showing that $\mathrm{HCO}_{3}^{-}$in the seminal fluid was needed for motility initiation $^{17}$ and that this anion was able to increase cAMP levels through direct stimulation of a unique type of adenylyl cyclase present in sperm. More than a decade later, this unique cyclase was cloned from rat testis. Since it is found in a soluble fraction of the testis, it was called SACY. ${ }^{103}$ Although it is not clear whether SACY has a role in germ cell differentiation, SACY knockout mice are sterile. ${ }^{104}$ The sterility phenotype is mapped to lack of capacitation; in particular sperm from the SACY null mice are not able to move actively and cannot hyperactivate. ${ }^{105}$ Unexpectedly, these sperm have no obvious problems with their ability to undergo a $\mathrm{ZP}$-induced acrosome reaction, suggesting that this event can be dissociated from other capacitation-associated processes. ${ }^{104}$

\section{Role of PKA as a target of cAMP}

Over the years the role of cAMP in the regulation of sperm has been supported by biochemical and pharmacological approaches. It is well established that inhibitors of PKA such as H89, rpScAMP and the peptide protein kinase inhibitor ${ }^{106,107}$ block sperm motility and other downstream signaling pathways (see below). Although cAMP has multiple targets, these experiments suggested that PKA has a relevant role in capacitation. Consistent with this hypothesis, mammalian sperm contain a specific splicing variant of the PKA catalytic subunit alpha, C $\alpha 2 \cdot{ }^{108,109}$ When the unique $\mathrm{C} \alpha 2$ exon is eliminated by homologous recombination, mice are sterile without presenting other problems. The sterility is due to defects in sperm capacitation that are phenotypically similar to the ones observed for the SACY knockout. ${ }^{109}$ More recently, the same group has engineered another mouse model in which exon 5 of the PKA catalytic $\alpha$-subunit was replaced with a mutant form displaying a point mutation in the ATP-binding pocket. ${ }^{10}$ Although this mutation is silent and PKA in this mice is able to perform its normal functions, this mutant, named C $\alpha \mathrm{M} 120 \mathrm{~A}$, is now sensitive to a bulky inhibitor such as 1NM-PP1, which is inactive against the wild-type PKA. Using sperm of these mice in vitro, the authors clearly showed PKA is required for the activation of flagellar beat and for the flagellar waveform asymmetry associated with hyperactivation. ${ }^{110}$

\section{Events downstream of PKA activation}

Using the mouse as experimental model, it was shown that sperm capacitation is associated with an increase in protein tyrosine phosphorylation. ${ }^{111}$ This work indicated that $\mathrm{HCO}_{3}^{-}, \mathrm{Ca}^{2+}$ and bovine serum albumin (or other cholesterol acceptors) were needed to support capacitation as well as the increase in tyrosine phosphorylation. Following studies demonstrated that glucose, ${ }^{112} \mathrm{Na}^{+}$and $\mathrm{Cl}^{-}$were also essential for capacitation and for the increase in phosphorylation $^{76,96}$. Interestingly, the lack of protein tyrosine phosphorylation in the absence of each of these capacitation medium elements was reversed by activation of a cAMP pathway. ${ }^{96}$ Moreover, in complete medium, PKA inhibitors such as H89 or Rp-cAMPS were able to block the increase in tyrosine phosphorylation. ${ }^{107}$ Altogether, these data indicated that the increase in protein tyrosine phosphorylation was downstream of cAMP synthesis and activation of PKA. The role of cAMP in the increase in tyrosine phosphorylation has been further analyzed using genetically modified mice models.

SACY, C $\alpha 2$ and AKAP4 are three genes essential for the function of the cAMP/PKA pathway in sperm. Elimination of each of these genes resulted in a male sterile phenotype. ${ }^{113}$ All these null mice presented defects in the regulation of the protein tyrosine phosphorylation pathway as well as in several other capacitation-related events such as the onset of hyperactivated motility. ${ }^{104,114,115}$ In addition, sperm lacking AKAP4 presented morphological flagellar defects likely due to the role of this protein in tail assembly. ${ }^{115}$ Consistent with a role of PKA upstream the capacitation-associated increase in tyrosine phosphorylation, the aforementioned sperm from C $\alpha \mathrm{M} 120 \mathrm{~A}$-expressing mouse lines did not undergo capacitation-associated changes in tyrosine phosphorylation when the mutated PKA was blocked by the bulky inhibitor 1NM-PP1. ${ }^{110}$

Despite the fact that many groups have shown similar regulatory pathways in sperm from other species, there is still a limited knowledge on the identity and the role of proteins phosphorylated in tyrosine residues. One of the first proteins to be identified as a substrate for tyrosine phosphorylation was human AKAP4. ${ }^{116}$ Tyrosine phosphorylation of this protein was also demonstrated in hamster sperm ${ }^{117}$ and the exact sites of tyrosine phosphorylation were mapped. ${ }^{118}$ Other proteins known to be tyrosine phosphorylated in mammalian sperm are the valosin-containing protein, AKAP3 and CABYR, ${ }^{118,119}$ a sperm-specific aldolase and pyruvate hydrogenase. ${ }^{74,120}$ The role of these phosphorylations has not yet been elucidated; however, it is speculated that tyrosine phosphorylation may regulate either the activity or the location of these enzymes.

\section{Regulation of tyrosine phosphorylation: role of Src kinase family and ser/thr phosphatases}

Another area of inquiry in the last years has been the identification of the tyrosine kinase(s) responsible for the observed changes in protein tyrosine phosphorylation accompanying the capacitation process. Recently, several groups have demonstrated the presence of $\mathrm{cSrc}$ in mouse and human sperm. ${ }^{121-124}$ These publications also presented evidence that cSrc inhibitors blocked the capacitation-associated increase in tyrosine phosphorylation. These results were consistent with the hypothesis that cSrc plays a 
role in the regulation of tyrosine phosphorylation in sperm. Challenging this conclusion, experiments conducted with sperm from cSrc null mice demonstrated that at least in this species, cSrc either is not essential for the increase in tyrosine phosphorylation or it can be replaced by other kinase in the cSrc null sperm. ${ }^{125}$ Other results in this work indicated that cSrc family kinase inhibitors such as Bosutinib (SKI606) and SU6656 significantly reduced sperm motility parameters, and blocked IVF. These compounds blocked the increase in tyrosine phosphorylation; although this action was expected, these inhibitors also prevented direct phosphorylation by PKA, an event upstream of the increase in tyrosine phosphorylation. This observation was not explained by an unspecific effect of the cSrc inhibitors on PKA activity as shown using an in vitro kinase assay. Altogether, these results suggested the participation of a member of cSrc family kinase in the regulation of capacitation; however, they also indicated that a cSrc family member was upstream or parallel to the PKA activation and not an effector of this signaling pathway. It has been established that cSrc kinases can regulate the activity of ser/thr phosphatases. In particular, the PP2A catalytic subunit exhibits a cSrc consensus phosphorylation site (TPDYFL) in its C-terminal domain that when phosphorylated downregulates its activity. If this pathway was active in sperm, it is predicted that inhibition of cSrc would result in upregulation of PP2A activity with a consequent dephosphorylation of ser/thr-phosphorylated substrates. Indeed, addition of low concentrations of okadaic acid or calyculin, two specific ser/thr phosphatase inhibitors, completely reversed the action of the cSrc inhibitors strongly suggesting that the role of a cSrc family kinase was mediated by a ser/thr phosphatase $^{125}$ (Figure 2).

\section{Other phosphorylation pathways observed during sperm capacitation}

Although most is known about the regulation of the cAMP/PKA pathway and the downstream increase in tyrosine phosphorylation, several other protein kinases are present in sperm and are likely to play a role

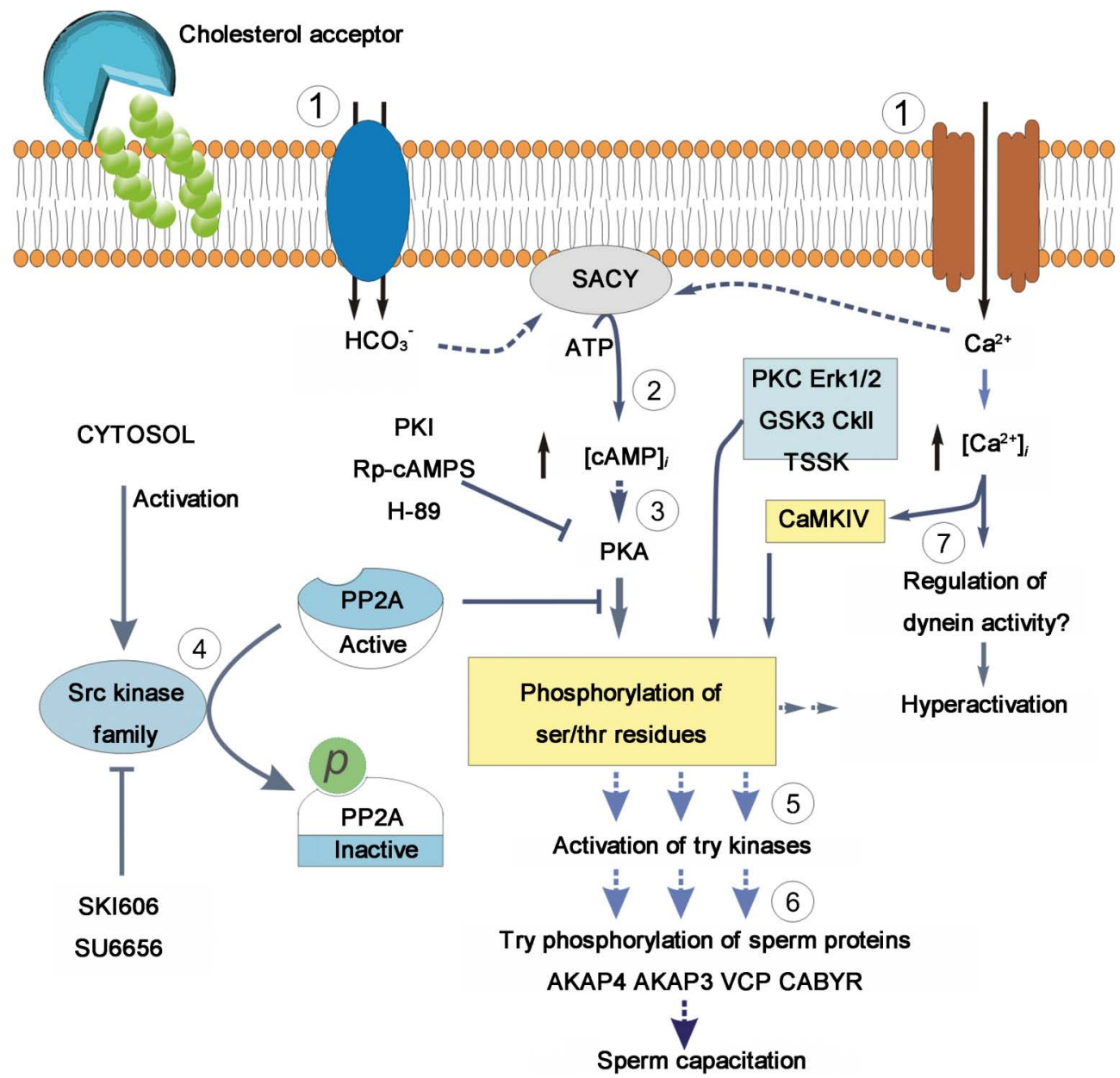

Figure 2 Model of the regulation of phosphorylation pathways during mammalian sperm capacitation. The overall pathway is modulated by cholesterol removal of sperm plasma membrane. (1) Influx of $\mathrm{HCO}_{3}{ }^{-}$and $\mathrm{Ca}^{2+}$ stimulates an SACY. (2) Increasing intracellular cAMP concentrations. (3) High cAMP levels activate PKA. This activation can be blocked in vitro by addition of the inhibitors H-89, Rp-cAMPs and the peptide PKI. (4) In vivo, phosphorylation of PKA substrates is subjected to regulation by a ser/thr phosphatase, likely PP2A. This phosphatase is in turn downregulated by a member of the Src kinase family by still unknown mechanisms. Activation of Src kinase family members can be blocked by in vitro addition of the inhibitors SU6656 or SKI-606 (Bosutinib). The onset of PKA substrates phosphorylation is followed by activation of unidentified tyrosine kinases (5) and the promotion of tyrosine phosphorylation of sperm proteins (6) (e.g., AKAP4, AKAP3, VCP and CABYR). (7) Intracellular $\mathrm{Ca}^{2+}$ increase might affect the axoneme directly, through selective regulation of dyneins. In addition, Ca ${ }^{2+}$ upregulates CaMKIV, leading to hyperactivation. PKA, protein kinase A; PKC, protein kinase C; PKI, protein kinase inhibitor; SACY, soluble adenylyl cyclase; VCP, valosincontaining protein. 
in the regulation of sperm capacitation. Different PKC isoforms have been described in mammalian sperm. ${ }^{126,127}$ For example, phorbol esters stimulate these kinases and change sperm motility, ${ }^{128}$ the acrosome reaction ${ }^{129}$ and cAMP levels. ${ }^{130}$ Even though these phorbol ester effects are likely to be mediated by PKC, the possibility that other phorbol ester receptors such as chimaerins are present in sperm cannot be discarded. ${ }^{131}$ Other ser/thr protein kinases reported in sperm are: Erk $1 / 2 ;{ }^{132,133}$ GSK $3 ;^{134}$ CaMKIV; ${ }^{135}$ and casein kinase II, ${ }^{136} \mathrm{mem}-$ bers of the testis-specific serine kinase family. ${ }^{137}$ Interestingly, prolinedirected phosphorylation appears to be regulated by cholesterol efflux. ${ }^{138}$ Altogether, this evidence suggests that in addition to PKA, other kinases are involved in sperm capacitation; however, more research is needed to explain how they interact with other capacitation-associated pathways.

\section{Model of the regulation of phosphorylation during capacitation} During the last years, the textbook model of sperm capacitation has been linear. In this model, $\mathrm{Ca}^{2+}$ and $\mathrm{HCO}_{3}^{-}$were involved in the activation of a cAMP/PKA pathway through the regulation of SACY. The finding that cSrc inhibitors obliterated phosphorylation of PKA substrates, without inhibiting PKA activation, has the implication that capacitation is also dependent on the activation of a second pathway. As part of this pathway, it is predicted that capacitation will also require the activation of a cSrc family kinase and that this activation will result in phosphorylation and downregulation of a ser/thr phosphatase. In parallel, activation of SACY with the consequent increase in cAMP synthesis will activate PKA. Both processes are needed to induce the increase in phosphorylation observed during sperm capacitation. How different components of the capacitation media interact to activate these pathways warrant future investigation (Figure 2).

\section{LIPIDS IN SPERM CAPACITATION}

\section{Phospholipid transferases}

It is now well established that phospholipids in the bilayer structure of cell membranes are distributed asymmetrically. ${ }^{139}$ Under normal conditions, lipid distribution among the inner and the outer leaflet of the plasma membrane is maintained by the combined activity of several phospholipid transferases: an aminophospholipid transferase ('flippase') that moves phosphatidylserine and phosphatidylethanolamine from the outer to the inner leaflet; ${ }^{140}$ a nonspecific phospholipid transferase ('floppase') that transfers phospholipids from the inner to the outer leaflet; ${ }^{141}$ and a bidirectional carrier ('scramblase') that moves all phospholipids in both directions across the membrane bilayer. ${ }^{142}$ Under certain conditions, the normal phospholipid asymmetry maintained throughout cell life collapses, with the result that phosphatidylserine and phosphatidylethanolamine appear in the outer leaflet. Among other situations, such collapse (also known as 'scrambling') is seen during lymphocyte activation, red blood cell ageing and apoptosis. ${ }^{143-145}$

In sperm, scrambling is observed as an early capacitation event. ${ }^{146,147}$ Analysis of phospholipid movements strongly suggests that the collapse of phospholipid asymmetry in these cells is due to an increase in the activity of a sperm scramblase. ${ }^{146}$ Moreover, the change in phospholipid distribution appears to be stimulated by $\mathrm{HCO}_{3}^{-}$, mediated by a cAMP/PKA pathway and enhanced by protein phosphatase inhibitors. ${ }^{146,147}$ Importantly, while scrambling is a wellknown characteristic of apoptosis (programmed cell death), there is evidence suggesting that the $\mathrm{HCO}_{3}^{-}$-induced scrambling in sperm is not related to this process. ${ }^{148}$ Although the role of phospholipid scrambling in sperm capacitation is not well understood, it is likely to be connected with the need for serum albumin in this process. Phospholipid scrambling may facilitate albumin-mediated cholesterol extraction. ${ }^{146,149}$ Though serum albumin may have other roles during capacitation such as promoting $\mathrm{Ca}^{2+}$ influx, ${ }^{150,151}$ its ability to facilitate cholesterol efflux is required for capacitation. Capacitation is blocked by addition of cholesterol and/or cholesterol analogs to the capacitation medium. ${ }^{152}$ Furthermore, serum albumin can be substituted by cholesterol-binding compounds such as high-density lipoproteins $^{152,153}$ and $\beta$-cyclodextrins ${ }^{154-157}$ to induce capacitation in vitro.

\section{Cholesterol removal and lipid rafts}

In spite of the fact that cholesterol efflux is involved in sperm capacitation, how this efflux modulates sperm physiology is not well understood. Possibly cholesterol concentrates in specialized sperm plasma membrane microdomains, also known as rafts. ${ }^{154-159}$ Despite controversies regarding the methods used to obtain these rafts, ${ }^{160}$ alternative approaches have emerged to identify proteins in these domains. ${ }^{161}$ Several protein markers for these structures have been found in the sperm such as caveolin1 and cavelin2, as well as flotilin 1 and $2 .^{161-164}$ Most interestingly, sphingolipids such as GM1 and GM3 are also present in these cells. In the case of GM1, a capacitation-associated movement of this sphingolipid has been observed. ${ }^{165,166}$ Using fluorescent cholera toxin-B subunit to track GM1 in mouse sperm may allow following capacitation in the female tract. ${ }^{166}$ In addition, it has recently been proposed that GM1 binds decapacitation factors that are released as part of the capacitation process. ${ }^{167}$

In other cell types, lipid rafts bring protein assemblies together; it is predicted that changes in the cholesterol/phospholipid ratio within these structures can modulate their size and behavior. ${ }^{168,169}$ In somatic cells, cholesterol-binding reagents such as beta-cyclodextrins, are capable of activating signaling pathways, for example, those involving tyrosine kinases, $G$ proteins and/or other molecules. ${ }^{170-172}$ As mentioned, the release of cholesterol accompanies sperm capacitation and correlates with an increase in protein phosphorylation. A working hypothesis consistent with this observation is that activation of raft complexes by cholesterol release and the regulation of phosphorylation pathways are coordinated and form part of the same signaling pathway. Alternatively or complementary to this hypothesis, changes in lateral mobility of membrane proteins as a consequence of cholesterol loss might be responsible for capacitation. ${ }^{173}$

\section{FINAL REMARKS}

In view of the notion that the maturational process undergone by mammalian sperm in the female reproductive tract known as capacitation is essential for fertilization, there is a need to unravel the molecular processes involved in this complex and fundamental process. The discovery of sperm capacitation over 50 years ago opened new possibilities and a whole new era of reproductive medicine. However, while key aspects of capacitation including ionic transport, PKA stimulation and tyrosine phosphorylation of sperm proteins have significantly advanced, their functional interrelation is still not clearly understood. An initial fast bicarbonate-induced PKA activation appears to trigger capacitation both in the female tract and in in vitro systems. However, further work is needed to identify the ionic fluxes involved, the spatial PKA substrate arrangements and their signaling roles, as well as the sperm cAMP-dependent processes that are PKAindependent. Exciting new imaging, proteomic and electrophysiological tools are allowing researchers to tackle these and other open 
questions in the field: What are the identities of the sperm proteins involved in capacitation that change their phosphorylation state? Which kinase(s) and phosphatases are responsible for modulating their function and interaction, and how are they regulated? Which are the identities of the transporters responsible for the key ion fluxes necessary for capacitation and how are they intertwined with the modulation of second messengers and phosphorylation changes? Are hyperactivation and capacitation parallel or independent and what is the role of the sperm-specific ionic channels CatSper and Slo3 in both processes? Is the concept of capacitation extensive to other species? Addressing such unsolved questions will bring fundamental progress into this fascinating field helping to set a better ground base for developing new infertility treatments, diagnostics and contraceptive techniques.

\section{COMPETING FINANCIAL INTERESTS}

The authors declare no competing financial interest.

\section{ACKNOWLEDGMENTS}

This work was supported by Dirección General de Asuntos del Personal Académico (DGAPA): IN211809 (to AD), CONACyT: 49113 (to AD), NIH: R01 HD44044 (to PEV) and HD038082 (to PEV and AD).

1 Steptoe PC, Edwards RG. Birth after the reimplantation of a human embryo. Lancet 1978; 2: 366

2 Austin CR. The capacitation of the mammalian sperm. Nature 1952; 170: 326

3 Chang MC. Fertilizing capacity of spermatozoa deposited into the fallopian tubes. Nature 1951; 168: 697-8.

4 Chang MC. Fertilization of rabbit ova in vitro. Nature 1959; 184 (Suppl 7): 466-7.

5 Suarez SS. Regulation of sperm storage and movement in the mammalian oviduct. Int J Dev Biol 2008; 52: 455-62.

6 Florman HM, Jungnickel MK, Sutton KA. Regulating the acrosome reaction. Int J Dev Biol 2008; 52: 503-10.

7 Bailey JL. Factors regulating sperm capacitation. Syst Biol Reprod Med 2010; 56 334-48.

8 Aitken RJ, Baker MA. The role of proteomics in understanding sperm cell biology. Int $J$ Androl 2008; 31: 295-302.

9 Brewis IA, Gadella BM. Sperm surface proteomics: from protein lists to biological function. Mol Hum Reprod 2010; 16: 68-79.

10 Darszon A, Labarca P, Nishigaki T, Espinosa F. Ion channels in sperm physiology. Physiol Rev 1999; 79: 481-510.

11 Fraser LR. The 'switching on' of mammalian spermatozoa: molecular events involved in promotion and regulation of capacitation. Mol Reprod Dev 2010; 77: 197-208.

12 Abou-Haila A, Tulsiani DR. Signal transduction pathways that regulate sperm capacitation and the acrosome reaction. Arch Biochem Biophys 2009; 485: 72-81.

13 Hille B. Ion Channels of Excitable Membranes. Sunderland, , MA: Sinauer Associates Inc.; 2001.

14 Turner TT. Necessity's potion: inorganic ions and small organic molecules in the epididymal lumen. In: Robaire B, Hinton B, editors. The Epididymis: From Molecules to Clinical Practice. A Comprehensive Survey of the Efferent Ducts, the Epididymis, and the Vas Deferens. New York: Kluwer Academic/Plenum; 2002. p131.

15 Shum WW, da Silva N, Brown D, Breton S. Regulation of luminal acidification in the male reproductive tract via cell-cell crosstalk. J Exp Biol 2009; 212: 1753-61.

16 Asari M, Sasaki K, Miura K, Ichihara N, Nishita T. Immunohistolocalization of the carbonic anhydrase isoenzymes (CA-I, CA-II, and CA-III) in the reproductive tract of male horses. Am J Vet Res 1996; 57: 439-43.

17 Okamura N, Tajima Y, Soejima A, Masuda H, Sugita Y. Sodium bicarbonate in semina plasma stimulates the motility of mammalian spermatozoa through direct activation of adenylate cyclase. J Biol Chem 1985; 260: 9699-705.

18 Maas DH, Storey BT, Mastroianni L Jr. Hydrogen ion and carbon dioxide content of the oviductal fluid of the rhesus monkey (Macaca mulatta). Fertil Steril 1977; 28: 981-5.

19 Visconti PE, Westbrook VA, Chertihin O, Demarco I, Sleight S et al. Novel signaling pathways involved in sperm acquisition of fertilizing capacity. J Reprod Immunol 2002; 53: 133-50.

20 Yanagimachi R. Physiology of reproduction. In: Knobil E, Neill J, editors. Mammalian Fertilization. New York: Raven Press; 1994. p189.

21 Parrish JJ, Susko-Parrish JL, First NL. Capacitation of bovine sperm by heparin: inhibitory effect of glucose and role of intracellular pH. Biol Reprod 1989; 41 683-99.

22 Zeng $\mathrm{Y}$, Oberdorf JA, Florman HM. pH regulation in mouse sperm: identification of $\mathrm{Na}^{+}-, \mathrm{Cl}^{-}$, and $\mathrm{HCO}_{3}^{-}$-dependent and arylaminobenzoate-dependent regulatory mechanisms and characterization of their roles in sperm capacitation. Dev Biol 1996; 173: 510-20.

23 Baldi E, Casano R, Falsetti C, Krausz C, Maggi M et al. Intracellular calcium accumulation and responsiveness to progesterone in capacitating human spermatozoa. J Androl 1991; 12: 323-30.

24 Dasgupta S, Mills CL, Fraser LR. $\mathrm{Ca}^{2+}$-related changes in the capacitation state of human spermatozoa assessed by a chlortetracycline fluorescence assay. J Reprod Fertil 1993; 99: 135-43.

25 Galantino-Homer HL, Florman HM, Storey BT, Dobrinski I, Kopf GS. Bovine sperm capacitation: assessment of phosphodiesterase activity and intracellular alkalinization on capacitation-associated protein tyrosine phosphorylation. Mol Reprod Dev 2004; 67: 487-500.

26 Lishko PV, Botchkina IL, Fedorenko A, Kirichok Y. Acid extrusion from human spermatozoa is mediated by flagellar voltage-gated proton channel. Cell 2010; 140 327-37.

27 Marin-Briggiler CI, Gonzalez-Echeverria F, Buffone M, Calamera JC, Tezon JG et al. Calcium requirements for human sperm function in vitro. Fertil Steril 2003; 79 1396-403.

28 Fraser LR. Minimum and maximum extracellular $\mathrm{Ca}^{2+}$ requirements during mouse sperm capacitation and fertilization in vitro. J Reprod Fertil 1987; 81: 77-89.

29 Bouschet T, Henley JM. Calcium as an extracellular signalling molecule: perspectives on the calcium sensing receptor in the brain. C R Biol 2005; 328: 691-700.

30 Carlson AE, Hille B, Babcock DF. External $\mathrm{Ca}^{2+}$ acts upstream of adenylyl cyclase SACY in the bicarbonate signaled activation of sperm motility. Dev Biol 2007; 312 183-92.

31 Cai X, Clapham DE. Evolutionary genomics reveals lineage-specific gene loss and rapid evolution of a sperm-specific ion channel complex: CatSpers and CatSperbeta. PLoS One 2008; 3: e3569.

32 Navarro B, Kirichok Y, Chung JJ, Clapham DE. Ion channels that control fertility in mammalian spermatozoa. Int J Dev Biol 2008; 52: 607-13.

33 Ho K, Wolff CA, Suarez SS. CatSper-null mutant spermatozoa are unable to ascend beyond the oviductal reservoir. Reprod Fertil Dev 2009; 21 : 345-50.

34 Ren D, Xia J. Calcium signaling through CatSper channels in mammalian fertilization. Physiology (Bethesda) 2010; 25: 165-75.

35 Lishko PV, Kirichok Y. The role of Hv1 and CatSper channels in sperm activation. J Physiol 2010; 588: 4667-72.

36 Hildebrand MS, Avenarius MR, Fellous M, Zhang Y, Meyer NC et al. Genetic male infertility and mutation of CATSPER ion channels. Eur J Hum Genet2010; 18: 1178 84.

37 Liu J, Xia J, Cho KH, Clapham DE, Ren D. CatSperbeta, a novel transmembrane protein in the CatSper channel complex. J Biol Chem 2007; 282: 18945-52.

38 Wang H, Liu J, Cho KH, Ren D. A novel, single, transmembrane protein CATSPERG is associated with CATSPER1 channel protein. Biol Reprod 2009; 81: 539-44.

39 Wang H, Liu J, Cho KH, Ren D. A novel, single, transmembrane protein CATSPERG is associated with CATSPER1 channel protein. Biol Reprod 2009; 81: 539-44.

40 Qi H, Moran MM, Navarro B, Chong JA, Krapivinsky G et al. All four CatSper ion channel proteins are required for male fertility and sperm cell hyperactivated motility. Proc Natl Acad Sci USA 2007; 104: 1219-23.

41 Carlson AE, Westenbroek RE, Quill T, Ren D, Clapham DE et al. CatSper 1 required for evoked $\mathrm{Ca}^{2+}$ entry and control of flagellar function in sperm. Proc Natl Acad Sci USA 2003; 100: 14864-8.

42 Kirichok Y, Navarro B, Clapham DE. Whole-cell patch-clamp measurements of spermatozoa reveal an alkaline-activated $\mathrm{Ca}^{2+}$ channel. Nature 2006; 439: 737-40.

43 Wiesner B, Weiner J, Middendorff R, Hagen V, Kaupp UB et al. Cyclic nucleotide-gated channels on the flagellum control $\mathrm{Ca}^{2+}$ entry into sperm. J Cell Biol 1998; 142: 47384

44 Xia J, Ren D. Egg coat proteins activate calcium entry into mouse sperm via CATSPER channels. Biol Reprod 2009; 80: 1092-8.

45 Darszon A, Acevedo JJ, Galindo BE, Hernández-González EO, Nishigaki T et al. Sperm channel diversity and functional multiplicity. Reproduction 2006; 131: 977-88.

46 Arnoult C, Cardullo RA, Lemos JR, Florman HM. Activation of mouse sperm T-type $\mathrm{Ca}^{2+}$ channels by adhesion to the egg zona pellucida. Proc Natl Acad Sci USA 1996; 93: 13004-9.

47 Liévano A, Santi CM, Serrano CJ, Treviño CL, Bellvé AR et al. T-type $\mathrm{Ca}^{2+}$ channels and alpha1E expression in spermatogenic cells, and their possible relevance to the sperm acrosome reaction. FEBS Lett 1996; 388: 150-4

48 Publicover SJ, Barratt CL. Voltage-operated $\mathrm{Ca}^{2+}$ channels and the acrosome reaction: which channels are present and what do they do? Hum Reprod 1999; 14 873-9.

49 Martínez-López P, Santi CM, Treviño CL, Ocampo-Gutiérrez AY, Acevedo JJ et al. Mouse sperm $\mathrm{K}^{+}$currents stimulated by $\mathrm{pH}$ and CAMP possibly coded by $\mathrm{Slo3}$ channels. Biochem Biophys Res Commun 2009; 381: 204-9.

50 Perez-Reyes E. Molecular physiology of low-voltage-activated t-type calcium channels. Physiol Rev 2003; 83: 117-61.

51 Arnoult C, Kazam IG, Visconti PE, Kopf GS, Villaz M et al. Control of the low voltageactivated calcium channel of mouse sperm by egg ZP3 and by membrane hyperpolarization during capacitation. Proc Natl Acad Sci USA 1999: 96: 6757-62.

52 Santi CM, Darszon A, Hernandez-Cruz A. A dihydropyridine-sensitive T-type $\mathrm{Ca}^{2+}$ current is the main $\mathrm{Ca}^{2+}$ current carrier in mouse primary spermatocytes. $\mathrm{Am} \mathrm{J}$ Physiol 1996; 271: C1583-93.

53 José O, Hernández-Hernández O, Chirinos M, González-González ME, Larrea F et al. Recombinant human ZP3-induced sperm acrosome reaction: evidence for the 
involvement of T- and L-type voltage-gated calcium channels. Biochem Biophys Res Commun 2010; 395: 530-4.

54 Choi S, Na HS, Kim J, Lee J, Lee S et al. Attenuated pain responses in mice lacking Cay3.2 T-type channels. Genes Brain Behav 2007; 6: 425-31.

55 Stamboulian S, Kim D, Shin HS, Ronjat M, de Waard M et al. Biophysical and pharmacological characterization of spermatogenic T-type calcium current in mice lacking the Cav3.1 (alpha1G) calcium channel: Cav3.2 (alpha1H) is the main functional calcium channel in wild-type spermatogenic cells. J Cell Physiol 2004; 200: 116-24.

56 Escoffier J, Boisseau S, Serres C, Chen CC, Kim D et al. Expression, localization and functions in acrosome reaction and sperm motility of $\mathrm{Ca}_{\mathrm{v}} 3.1$ and $\mathrm{Ca}_{\mathrm{v}} 3.2$ channels in sperm cells: an evaluation from Cav3.1 and Cav3.2 deficient mice. J Cell Physiol 2007; 212: 753-63.

57 Wennemuth G, Westenbroek RE, Xu T, Hille B, Babcock DF. Cav2.2 and Cav2.3 (Nand R-type) $\mathrm{Ca}^{2+}$ channels in depolarization-evoked entry of $\mathrm{Ca}^{2+}$ into mouse sperm. J Biol Chem 2000; 275: 21210-7.

58 Darszon A, Nishigaki T, Beltran C, Trevino CL. Calcium channels in the development, maturation and function of spermatozoa. Physiol Rev 2011

59 Florman HM, Arnoult C, Kazam IG, Li C, O'Toole CM. A perspective on the control of mammalian fertilization by egg-activated ion channels in sperm: a tale of two channels. Biol Reprod 1998; 59: 12-6.

60 Demarco IA, Espinosa F, Edwards J, Sosnik J, de la Vega-Beltran JL et al. Involvement of a $\mathrm{Na}^{+} / \mathrm{HCO}_{3}^{-}$cotransporter in mouse sperm capacitation. J Biol Chem 2003; 278: 7001-9.

61 Casey JR, Grinstein S, Orlowski J. Sensors and regulators of intracellular pH. Nat Rev Mol Cell Biol 2010; 11: 50-61.

62 Quill TA, Wang D, Garbers DL. Insights into sperm cell motility signaling through sNHE and the CatSpers. Mol Cell Endocrinol 2006; 250: 84-92.

63 Wang D, King SM, Quill TA, Doolittle LK, Garbers DL. A new sperm-specific $\mathrm{Na}^{+} / \mathrm{H}^{+}$ exchanger required for sperm motility and fertility. Nat Cell Biol 2003; 5: 1117-22.

64 Catterall WA. Structure and regulation of voltage-gated $\mathrm{Ca}^{2+}$ channels. Annu Rev Cell Dev Biol 2000; 16: 521-55.

65 Wang D, Hu J, Bobulescu IA, Quill TA, McLeroy P et al. A sperm-specific $\mathrm{Na}^{+} / \mathrm{H}^{+}$ exchanger (sNHE) is critical for expression and in vivo bicarbonate regulation of the soluble adenylyl cyclase (sAC). Proc Natl Acad Sci USA 2007; 104: 9325-30.

66 Musset B, Capasso M, Cherny VV, Morgan D, Bhamrah M et al. Identification of Thr29 as a critical phosphorylation site that activates the human proton channel Hvcn1 in leukocytes. J Biol Chem 2010; 285: 5117-21.

67 Munoz-Garay C, de la Vega-Beltran JL, Delgado R, Labarca P, Felix R et al. Inwardly rectifying $\mathrm{K}^{+}$channels in spermatogenic cells: functional expression and implication in sperm capacitation. Dev Biol 2001; 234: 261-74.

68 Zeng Y, Clark EN, Florman HM. Sperm membrane potential: hyperpolarization during capacitation regulates zona pellucida-dependent acrosomal secretion. Dev Biol 1995; 171: 554-63.

69 Hernández-González EO, Treviño CL, Castellano LE, de la Vega-Beltrán JL, Ocampo $\mathrm{AY}$ et al. Involvement of cystic fibrosis transmembrane conductance regulator in mouse sperm capacitation. J Biol Chem 2007; 282: 24397-406.

70 Acevedo JJ, Mendoza-Lujambio I, de la Vega-Beltran JL, Trevino CL, Felix R et al. KATP channels in mouse spermatogenic cells and sperm, and their role in capacitation. Dev Biol 2006; 289: 395-405.

71 Chan HC, Wu WL, Sun YP, Leung PS, Wong TP et al. Expression of sperm $\mathrm{Ca}^{2+}$. activated $\mathrm{K}^{+}$channels in Xenopus oocytes and their modulation by extracellular ATP. FEBS Lett 1998; 438: 177-82.

72 Felix R, Serrano CJ, Treviño CL, Muñoz-Garay C, Bravo A et al. Identification of distinct $\mathrm{K}^{+}$channels in mouse spermatogenic cells and sperm. Zygote 2002; 10: 183-8.

73 Salvatore L, D'Adamo MC, Polishchuk R, Salmona M, Pessia M. Localization and agedependent expression of the inward rectifier $\mathrm{K}^{+}$channel subunit Kir 5.1 in a mammalian reproductive system. FEBS Lett 1999; 449: 146-52.

74 Arcelay E, Salicioni AM, Wertheimer E, Visconti PE. Identification of proteins undergoing tyrosine phosphorylation during mouse sperm capacitation. Int J Dev Biol 2008; 52: 463-72.

75 Darszon A, Treviño CL, Wood C, Galindo B, Rodríguez-Miranda E et al. Ion channels in sperm motility and capacitation. Soc Reprod Fertil Supp/ 2007; 65: 229-44.

76 Hernández-González EO, Sosnik J, Edwards J, Acevedo JJ, Mendoza-Lujambio I et al. Sodium and epithelial sodium channels participate in the regulation of the capacitation-associated hyperpolarization in mouse sperm. J Biol Chem 2006; 281: 5623-33.

77 Kellenberger S, Schild L. Epithelial sodium channel/degenerin family of ion channels: a variety of functions for a shared structure. Physiol Rev 2002; 82: 735-67.

78 Awayda MS. Regulation of the epithelial $\mathrm{Na}^{+}$channel by intracellular $\mathrm{Na}^{+}$. Am J Physiol 1999; 277: C216-24.

79 Hur CG, Choe C, Kim GT, Cho SK, Park JY et al. Expression and localization of two-pore domain $\mathrm{K}^{+}$channels in bovine germ cells. Reproduction 2009; 137: 237-44.

80 Hibino $\mathrm{H}$, Inanobe A, Furutani K, Murakami S, Findlay I et al. Inwardly rectifying potassium channels: their structure, function, and physiological roles. Physiol Rev 2010; 90: 291-366.

81 Martínez-López P, Treviño CL, de la Vega-Beltrán JL, Blas GD, Monroy E et al. TRPM8 in mouse sperm detects temperature changes and may influence the acrosome reaction. J Cell Physiol; e-pub ahead of print 10 November 2010; doi: 10.1002/ jcp.22493.

82 Schreiber M, Wei A, Yuan A, Gaut J, Saito M et al. Slo3, a novel pH-sensitive $\mathrm{K}^{+}$ channel from mammalian spermatocytes. J Biol Chem 1998; 273: 3509-16.
83 Navarro B, Kirichok Y, Clapham DE. KSper, a pH-sensitive $\mathrm{K}^{+}$current that controls sperm membrane potential. Proc Natl Acad Sci USA 2007; 104: 7688-92.

84 Santi CM, Martínez-López P, de la Vega-Beltrán JL, Butler A, Alisio A et al. The SLO3 sperm-specific potassium channel plays a vital role in male fertility. FEBS Lett 2010; 584: 1041-6.

85 Zingman LV, Alekseev AE, Hodgson-Zingman DM, Terzic A. ATP-sensitive potassium channels: metabolic sensing and cardioprotection. J Appl Physiol 2007; 103: 188893.

86 Levitan I. Cholesterol and Kir channels. IUBMB Life 2009; 61: 781-90.

87 Salicioni AM, Platt MD, Wertheimer EV, Arcelay E, Allaire A et al. Signalling pathways involved in sperm capacitation. Soc Reprod Fertil Supp/ 2007; 65: 245-59.

88 Salkoff L, Butler A, Ferreira G, Santi C, Wei A. High-conductance potassium channels of the SLO family. Nat Rev Neurosci 2006; 7: 921-31.

89 Yang $\mathrm{CT}$, Zeng XH, Xia XM, Lingle CJ. Interactions between beta subunits of the KCNMB family and Slo3: beta4 selectively modulates Slo3 expression and function. PLoS One 2009; 4: e6135.

90 Salkoff L, Butler A, Ferreira G, Santi C, Wei A. High-conductance potassium channels of the SLO family. Nat Rev Neurosci 2006; 7: 921-31.

91 Tang QY, Zhang Z, Xia J, Ren D, Logothetis DE. Phosphatidylinositol 4,5-bisphosphate activates $\mathrm{Slo} 3$ currents and its hydrolysis underlies the epidermal growth factorinduced current inhibition. J Biol Chem 2010; 285: 19259-66.

92 Berdiev BK, Qadri YJ, Benos DJ. Assessment of the CFTR and ENaC association. Mol Biosyst 2009; 5: 123-7.

93 Rogers CS, Abraham WM, Brogden KA, Engelhardt JF, Fisher JT et al. The porcine lung as a potential model for cystic fibrosis. Am J Physiol Lung Cell Mol Physiol2008; 295: L240-63.

94 Xu WM, Shi QX, Chen WY, Zhou CX, Ni Y et al. Cystic fibrosis transmembrane conductance regulator is vital to sperm fertilizing capacity and male fertility. Proc Natl Acad Sci USA 2007; 104: 9816-21.

95 Chen WY, Xu WM, Chen ZH, Ni Y, Yuan YY et al. $\mathrm{Cl}^{-}$is required for $\mathrm{HCO}_{3}^{-}$entry necessary for sperm capacitation in guinea pig: involvement of a $\mathrm{Cl}^{-} / \mathrm{HCO}_{3}^{-}$ exchanger (SLC26A3) and CFTR. Biol Reprod 2009; 80: 115-23.

96 Wertheimer EV, Salicioni AM, Liu W, Trevino CL, Chavez J et al. Chloride Is essential for capacitation and for the capacitation-associated increase in tyrosine phosphorylation. J Biol Chem 2008; 283: 35539-50.

97 Russell JM. Sodium-potassium-chloride cotransport. Physiol Rev 2000; 80: 211 76.

98 Hess KC, Jones BH, Marquez B, Chen Y, Ord TS et al. The 'soluble' adenylyl cyclase in sperm mediates multiple signaling events required for fertilization. Dev Cell 2005; 9: 249-59.

99 Espinosa F, de la Vega-Beltran JL, Lopez-Gonzalez I, Delgado R, Labarca P et al. Mouse sperm patch-clamp recordings reveal single $\mathrm{Cl}^{-}$channels sensitive to niflumic acid, a blocker of the sperm acrosome reaction. FEBS Lett 1998; 426: 47-51.

100 Sato Y, Son JH, Meizel S. The mouse sperm glycine receptor/chloride channel: cellular localization and involvement in the acrosome reaction initiated by glycine. J Androl 2000; 21: 99-106.

101 Bray C, Son JH, Kumar P, Harris JD, Meizel S. A role for the human sperm glycine receptor $/ \mathrm{Cl}^{-}$channel in the acrosome reaction initiated by recombinant ZP3. Biol Reprod 2002; 66: 91-7.

102 Garbers DL, Tubb DJ, Hyne RV. A requirement of bicarbonate for $\mathrm{Ca}^{2+}$-induced elevations of cyclic AMP in guinea pig spermatozoa. J Biol Chem 1982; 257: 8980-4.

103 Braun T, Dods RF. Development of a $\mathrm{Mn}^{2+}$-sensitive, 'soluble' adenylate cyclase in rat testis. Proc Natl Acad Sci USA 1975; 72: 1097-101.

104 Xie F, Garcia MA, Carlson AE, Schuh SM, Babcock DF et al. Soluble adenylyl cyclase (sAC) is indispensable for sperm function and fertilization. Dev Biol2006; 296: 35362

105 Esposito G, Jaiswal BS, Xie F, Krajnc-Franken MA, Robben TJ et al. Mice deficient for soluble adenylyl cyclase are infertile because of a severe sperm-motility defect. Proc Natl Acad Sci USA 2004; 101: 2993-8.

106 Vijayaraghavan S, Goueli SA, Davey MP, Carr DW. Protein kinase A-anchoring inhibitor peptides arrest mammalian sperm motility. J Biol Chem 1997; 272: 4747-52.

107 Visconti PE, Moore GD, Bailey JL, Leclerc P, Connors SA et al. Capacitation of mouse spermatozoa. II. Protein tyrosine phosphorylation and capacitation are regulated by a cAMP-dependent pathway. Development 1995; 121: 1139-50.

108 Desseyn JL, Burton KA, McKnight GS. Expression of a nonmyristylated variant of the catalytic subunit of protein kinase A during male germ-cell development. Proc Nat Acad Sci USA 2000; 97: 6433-8.

109 Nolan MA, Babcock DF, Wennemuth G, Brown W, Burton KA et al. Sperm-specific protein kinase A catalytic subunit Calpha2 orchestrates cAMP signaling for male fertility. Proc Natl Acad Sci USA 2004; 101: 13483-8.

110 Morgan DJ, Weisenhaus M, Shum S, Su T, Zheng R et al. Tissue-specific PKA inhibition using a chemical genetic approach and its application to studies on sperm capacitation. Proc Natl Acad Sci USA 2008; 105: 20740-5.

111 Visconti PE, Bailey JL, Moore GD, Pan D, Olds-Clarke P et al. Capacitation of mouse spermatozoa. I. Correlation between the capacitation state and protein tyrosine phosphorylation. Development 1995; 121: 1129-37.

112 Urner F, Leppens-Luisier G, Sakkas D. Protein tyrosine phosphorylation in sperm during gamete interaction in the mouse: the influence of glucose. Biol Reprod 2001; 64: 1350-7.

113 Burton KA, McKnight GS. PKA, germ cells, and fertility. Physiology (Bethesda) 2007; 22: 40-6. 
114 Eddy EM. The scaffold role of the fibrous sheath. Soc Reprod Fertil Supp/ 2007; 65 : 45-62.

115 Miki K, Willis WD, Brown PR, Goulding EH, Fulcher KD et al. Targeted disruption of the Akap4 gene causes defects in sperm flagellum and motility. Dev Biol 2002; 248 331-42.

116 Carrera A, Moos J, Ning XP, Gerton GL, Tesarik J et al. Regulation of protein tyrosine phosphorylation in human sperm by a calcium/calmodulin-dependent mechanism: identification of A kinase anchor proteins as major substrates for tyrosine phosphorylation. Dev Biol 1996; 180: 284-96.

117 Jha KN, Shivaji S. Identification of the major tyrosine phosphorylated protein of capacitated hamster spermatozoa as a homologue of mammalian sperm a kinase anchoring protein. Mol Reprod Dev 2002; 61: 258-70.

118 Ficarro S, Chertihin O, Westbrook VA, White F, Jayes F et al. Phosphoproteome analysis of capacitated human sperm. Evidence of tyrosine phosphorylation of a kinase-anchoring protein 3 and valosin-containing protein/p97 during capacitation. J Biol Chem 2003; 278: 11579-89.

119 Li YF, He W, Kim YH, Mandal A, Digilio L et al. CABYR isoforms expressed in late steps of spermiogenesis bind with AKAPs and ropporin in mouse sperm fibrous sheath. Reprod Biol Endocrinol 2010; 8: 101.

120 Mitra K, Rangaraj N, Shivaji S. Novelty of the pyruvate metabolic enzyme dihydrolipoamide dehydrogenase in spermatozoa: correlation of its localization, tyrosine phosphorylation, and activity during sperm capacitation. J Biol Chem 2005; 280: 25743-53.

121 Baker MA, Hetherington L, Aitken RJ. Identification of SRC as a key PKA-stimulated tyrosine kinase involved in the capacitation-associated hyperactivation of murine spermatozoa. J Cell Sci 2006; 119: 3182-92.

122 Lawson C, Goupil S, Leclerc P. Increased activity of the human sperm tyrosine kinase SRC by the cAMP-dependent pathway in the presence of calcium. Biol Reprod 2008 79: 657-66

123 Mitchell LA, Nixon B, Baker MA, Aitken RJ. Investigation of the role of SRC in capacitation-associated tyrosine phosphorylation of human spermatozoa. Mol Hum Reprod 2008; 14: 235-43.

124 Varano G, Lombardi A, Cantini G, Forti G, Baldi E et al. Src activation triggers capacitation and acrosome reaction but not motility in human spermatozoa. Hum Reprod 2008; 23: 2652-62.

125 Krapf D, Arcelay E, Wertheimer EV, Sanjay A, Pilder SH et al. Inhibition of Ser/Th phosphatases induces capacitation-associated signaling in the presence of Src kinase inhibitors. J Biol Chem 2010; 285: 7977-85.

126 LaxY, Rubinstein S, Breitbart H. Subcellular distribution of protein kinase C alpha and betal in bovine spermatozoa, and their regulation by calcium and phorbol esters. Biol Reprod 1997; 56: 454-9.

127 Rotman T, Etkovitz N, Spiegel A, Rubinstein S, Breitbart H. Protein kinase A and protein kinase $\mathrm{C}_{\alpha}$ /PPP1CC2 play opposing roles in the regulation of phosphatidylinositol 3-kinase activation in bovine sperm. Reproduction 2010; 140: 43-56.

128 Rotem R, Paz GF, Homonnai ZT, Kalina M, Naor Z. Protein kinase C is present in human sperm: possible role in flagellar motility. Proc Natl Acad Sci USA 1990; 87 7305-8.

129 Naor Z, Breitbart H. Protein kinase $\mathrm{C}$ and mammalian spermatozoa acrosome reaction. Trends Endocrinol Metab 1997; 8: 337-42.

130 Visconti PE, Tezon JG. Phorbol esters stimulate cyclic adenosine 3', 5' monophosphate accumulation in hamster spermatozoa during in vitro capacitation. Biol Reprod 1989; 40: 223-31.

131 Colon-Gonzalez F, Kazanietz MG. C1 domains exposed: from diacylglycerol binding to protein-protein interactions. Biochim Biophys Acta 2006; 1761: 827-37.

132 Luconi M, Barni T, Vannelli GB, Krausz C, Marra F et al. Extracellular signal-regulated kinases modulate capacitation of human spermatozoa. Biol Reprod 1998; 58: 1476 89

133 de Lamirande E, Gagnon C. The extracellular signal-regulated kinase (ERK) pathway is involved in human sperm function and modulated by the superoxide anion. Mol Hum Reprod 2002; 8: 124-35.

134 Aquila S, Gentile M, Middea E, Catalano S, Morelli C et al. Leptin secretion by human ejaculated spermatozoa. J Clin Endocrinol Metab 2005; 90: 4753-61.

135 Marín-Briggiler $\mathrm{Cl}$, Jha KN, Chertihin O, Buffone MG, Herr JC et al. Evidence of the presence of calcium/calmodulin-dependent protein kinase IV in human sperm and its involvement in motility regulation. J Cell Sci 2005; 118: 2013-22.

136 Mudgal P, Anand SR. Casein kinase II activity of buffalo sperm chromatin. Mol Reprod Dev 1998; 50: 178-84.

137 LiY, Sosnik J, Brassard L, Reese M, Spiridonov NA etal. Expression and localization of five members of the testis-specific serine kinase (Tssk) family in mouse and human sperm and testis. Mol Hum Reprod; e-pub ahead of print 20 August 2010; doi 10.1093/molehr/gaq071.

138 Jha KN, Salicioni AM, Arcelay E, Chertihin O, Kumari S et al. Evidence for the involvement of proline-directed serine/threonine phosphorylation in sperm capacitation. Mol Hum Reprod 2006; 12: 781-9.

139 Daleke DL. Regulation of transbilayer plasma membrane phospholipid asymmetry. J Lipid Res 2003; 44: 233-42.

140 Tanaka K, Fujimura-Kamada K, Yamamoto T. Functions of phospholipid flippases. J Biochem 2011; 149: 131-43.

141 Wang L, Beserra C, Garbers DL. A novel aminophospholipid transporter exclusively expressed in spermatozoa is required for membrane lipid asymmetry and normal fertilization. Dev Biol 2004; 267: 203-15.

142 Bevers EM, Williamson PL. Phospholipid scramblase: an update. FEBS Lett 2010; 584: 2724-30.
143 Balasubramanian K, Schroit AJ. Aminophospholipid asymmetry: a matter of life and death. Annu Rev Physiol 2003; 65: 701-34.

144 Bevers EM, Comfurius P, Dekkers DW, Harmsma M, Zwaal RF. Transmembrane phospholipid distribution in blood cells: control mechanisms and pathophysiological significance. Biol Chem 1998; 379: 973-86.

145 Zachowski A. Phospholipids in animal eukaryotic membranes: transverse asymmetry and movement. Biochem J 1993; 294 (Pt 1)1-14.

146 Gadella BM, Harrison RA. The capacitating agent bicarbonate induces protein kinase A-dependent changes in phospholipid transbilayer behavior in the sperm plasma membrane. Development 2000; 127: 2407-20

147 Harrison RA, Miller NG. cAMP-dependent protein kinase control of plasma membrane lipid architecture in boar sperm. Mol Reprod Dev 2000; 55: 220-8.

148 de Vries KJ, Wiedmer T, Sims PJ, Gadella BM. Caspase-independent exposure of aminophospholipids and tyrosine phosphorylation in bicarbonate responsive human sperm cells. Biol Reprod 2003; 68: 2122-34

149 Flesch FM, Brouwers JF, Nievelstein PF, Verkleij AJ, van Golde LM et al. Bicarbonate stimulated phospholipid scrambling induces cholesterol redistribution and enables cholesterol depletion in the sperm plasma membrane. J Cell Sci 2001; 114: 3543 55.

150 Espinosa F, López-González I, Muñoz-Garay C, Felix R, de la Vega-Beltrán JL et al Dual regulation of the T-type $\mathrm{Ca}^{2+}$ current by serum albumin and beta-estradiol in mammalian spermatogenic cells. FEBS Lett 2000; 475: 251-6.

151 Xia J, Ren D. The BSA-induced $\mathrm{Ca}^{2+}$ influx during sperm capacitation is CATSPER channel-dependent. Reprod Biol Endocrinol 2009; 7: 119.

152 Visconti PE, Ning X, Fornés MW, Alvarez JG, Stein P et al. Cholesterol efflux-mediated signal transduction in mammalian sperm: cholesterol release signals an increase in protein tyrosine phosphorylation during mouse sperm capacitation. Dev Biol 1999, 214: 429-43

153 Therien I, Soubeyrand S, Manjunath P. Major proteins of bovine seminal plasma modulate sperm capacitation by high-density lipoprotein. Biol Reprod 1997; 57 1080-8.

154 Choi YH, Toyoda Y. Cyclodextrin removes cholesterol from mouse sperm and induces capacitation in a protein-free medium. Biol Reprod 1998; 59: 1328-33.

155 Osheroff JE, Visconti PE, Valenzuela JP, Travis AJ, Alvarez J et al. Regulation of human sperm capacitation by a cholesterol efflux-stimulated signal transduction pathway leading to protein kinase A-mediated up-regulation of protein tyrosine phosphorylation. Mol Hum Reprod 1999; 5: 1017-26.

156 Visconti PE, Galantino-Homer H, Ning X, Moore GD, Valenzuela JP et al. Cholestero efflux-mediated signal transduction in mammalian sperm. $\beta$-cyclodextrins initiate transmembrane signaling leading to an increase in protein tyrosine phosphorylation and capacitation. J Biol Chem 1999; 274: 3235-42.

157 Cross NL. Effect of methyl-beta-cyclodextrin on the acrosomal responsiveness of human sperm. Mol Reprod Dev 1999; 53: 92-8.

158 Simons K, Ikonen E. How cells handle cholesterol. Science 2000; 290: 1721-6.

159 Simons K, Vaz WL. Model systems, lipid rafts, and cell membranes. Annu Rev Biophys Biomol Struct 2004; 33: 269-95.

160 Shogomori $\mathrm{H}$, Brown DA. Use of detergents to study membrane rafts: the good, the bad, and the ugly. Biol Chem 2003; 384: 1259-63.

161 Asano A, Selvaraj V, Buttke DE, Nelson JL, Green KM et al. Biochemical characterization of membrane fractions in murine sperm: identification of three distinct sub-types of membrane rafts. J Cell Physiol 2009; 218: 537-48.

162 Miranda PV, Allaire A, Sosnik J, Visconti PE. Localization of low-density detergentresistant membrane proteins in intact and acrosome-reacted mouse sperm. Biol Reprod 2009; 80: 897-904.

163 Sleight SB, Miranda PV, Plaskett NW, Maier B, Lysiak J et al. Isolation and proteomic analysis of mouse sperm detergent-resistant membrane fractions: evidence for dissociation of lipid rafts during capacitation. Biol Reprod 2005; 73: 721-9.

164 Trevino CL, Serrano CJ, Beltran C, Felix R, Darszon A. Identification of mouse trp homologs and lipid rafts from spermatogenic cells and sperm. FEBS Lett 2001 509: 119-25.

165 Selvaraj V, Buttke DE, Asano A, McElwee JL, Wolff CA et al. GM1 dynamics as a marker for membrane changes associated with the process of capacitation in murine and bovine spermatozoa. J Androl 2007; 28: 588-99.

166 Bruckbauer A, Dunne PD, James P, Howes E, Zhou D et al. Selective diffusion barriers separate membrane compartments. Biophys J 2010; 99: L1-3.

167 Kawano N, Yoshida K, Iwamoto T, Yoshida M. Ganglioside GM1 mediates decapacitation effects of SVS2 on murine spermatozoa. Biol Reprod 2008; 79 1153-9.

168 Edidin M. Membrane cholesterol, protein phosphorylation, and lipid rafts. Sci STKE 2001; 2001: pe1.

169 Zajchowski LD, Robbins SM. Lipid rafts and little caves. Compartmentalized signalling in membrane microdomains. Eur J Biochem 2002; 269: 737-52.

170 Brown DA, London E. Functions of lipid rafts in biological membranes. Annu Rev Cell Dev Biol 1998; 14: 111-36.

171 Kabouridis PS, Janzen J, Magee AL, Ley SC. Cholesterol depletion disrupts lipid rafts and modulates the activity of multiple signaling pathways in T lymphocytes. Eur $\mathrm{J}$ Immunol 2000; 30: 954-63.

172 Roy S, Luetterforst R, Harding A, Apolloni A, Etheridge M et al. Dominant-negative caveolin inhibits $\mathrm{H}$-Ras function by disrupting cholesterol-rich plasma membrane domains. Nat Cell Biol 1999; 1: 98-105.

173 Jones R, Howes E, Dunne PD, James P, Bruckbauer A et al. Tracking diffusion of GM 1 gangliosides and zona pellucida binding molecules in sperm plasma membranes following cholesterol efflux. Dev Biol 2010; 339: 398-406. 